\title{
Cretaceous Subduction-Related Magmatism and Associated Porphyry-Type Cu-Mo Prospects in the Eastern Pontides, Turkey: New Constraints from Geochronology and Geochemistry
}

Okan Delibaş ${ }^{1,2, *}$, Robert Moritz ${ }^{2}$, Alexey Ulianov³ ${ }^{3}$ Massimo Chiaradia $^{2}$, Cem Saraç ${ }^{1}$, M. Kemal Revann ${ }^{4}$, and Deniz Göç ${ }^{4}$

1: Hacettepe University, Department of Geological Engineering, 06800, Beytepe-Ankara, Turkey

2: Department of Earth Sciences, University of Geneva, Rue des Maraîchers 13, 1205 Geneva, Switzerland

3: Institute of Earth Sciences, University of Lausanne, Géopolis, 1015, Lausanne, Switzerland

4: General Directorate of Mineral Research and Exploration (MTA), 06800, Ankara, Turkey

Corresponding author (Postal address: Hacettepe University, Department of Geological Engineering, 06800, Beytepe-Ankara/Turkey Phone: +905324714786, e-mail: delibaso@gmail.com).

Key words: Neotethys Ocean, Subduction-related magmatism, Porphyry-type mineralization, LA-ICP-MS U-Pb zircon dating, Eastern Pontides, Turkey. 


\begin{abstract}
This study focuses on the Elbeyli-Ordu, Emeksen-Giresun, Güzelyayla-Trabzon and Ulutaş-Ispir porphyry-type prospects located in the Eastern Pontides, Turkey. Our new LA-ICP-MS U-Pb zircon age data reveal that the Elbeyli-Ordu $\mathrm{Mo}-\mathrm{Cu}$ mineralization is hosted by a 77.0 $\pm 1.3 \mathrm{Ma}$-old monzonite/monzodiorite with a shoshonitic character. The Emeksen Mo mineralization, located $\sim 40 \mathrm{~km}$ southeast of the Elbeyli-Ordu prospect, consists of NW-and NE-striking quartz veins crosscuting a high-K calc-alkaline to shoshonitic granite dated at $78.5 \pm 0.8 \mathrm{Ma}$, a granodiorite dated at $78.7 \pm 0.5 \mathrm{Ma}$ and porphyry granite dated at $77.7 \pm 0.5 \mathrm{Ma}$. The Güzelyayla porphyry Cu-Mo prospect consists of a stockwork-type Cu-Mo mineralization crosscutting a calc-alkaline 81.4 $\pm 1.1 \mathrm{Ma}$-old dacite porphyry and Late Cretaceous calc-alkaline andesite. The Ispir-Ulutaş mineralization is hosted within a highly sericitized 131.1 \pm 0.9 Ma-old quartz-porphyry that intruded into a 132.9 $\pm 0.6 \mathrm{Ma}$-old calc-alkaline granite porphyry. Our new U-Pb zircon ages, lithogeochemical and radiogenic isotopic data of the host rocks associated with the porphyry-type prospects in the Eastern Pontides indicate that they formed in an arc-related environment during Cretaceous subduction of the Neotethys Ocean, and the IspirUlutas prospect is attributed to the main stage of the northward subduction of the Neotethys during the Early Cretaceous. We conclude that the Güzelyayla and Emeksen hydrothermal systems were formed during a transitional compressional to extensional tectonic evolution, whereas the Late Cretaceous Elbeyli hydrothermal system was emplaced during an extensional arc magmatic event. Highlyoxidized, high-K calc-alkaline to shoshonitic magmas at Emeksen and Elbeyli were derived from a metasomatised, heterogeneous and enriched lithospheric mantle, with variable degrees of partial melting of the mantle wedge and variable crustal contamination. Mixing/mingling processes between mafic magmas derived from the lower crust and acidic magmas at upper crustal levels played an important role in the formation of Cu-Mo porphyry-type mineralization in the Eastern Pontides.
\end{abstract}

\title{
1. Introduction
}

The EW-trending Pontides of northern Turkey was formed as a consequence of northward subduction of the Neotethys Ocean along the Eurasia margin during the Mesozoic, and was followed by final collision with the Anatolides-Taurides platform during the Cenozoic (Akıncı, 1984; Okay and Şahintürk, 1997; Şengör and Yılmaz, 1981). These successive tectonic environments resulted in the formation of volcanogenic massive sulfide (VMS)-, porphyry- and epithermal-type deposits and prospects related to calc-alkaline and adakitic magmatism. This study focuses on porphyry-type mineralizations (Fig. 1; Table 1) in the Eastern Pontides, which are associated to Cretaceous subduction-related calc-alkaline magmatism.

Although a number of porphyry-type Cu-Mo $\pm A u$ mineralizations (e.g. EmeksenGiresun; Güzelyayla-Trabzon; Berta-Artvin; Ulutaş-Erzurum) have been documented

in the Eastern Pontides since the 1970s (e.g. Giles, 1973; Soylu, 1999; Yalçınalp, 
1995; Yavuz, 1992;), most of the scientific ore deposit studies in the region and exploration efforts concentrated on VMS deposits (e.g. Akıncı, 1980; Çağatay and Boyle, 1977; Eyüboğlu et al., 2014; Pejatoviç, 1979; Revan, 2010; Revan et al., 2014). By contrast, genetic aspects and the investigation of the geological settings of porphyry-type mineralization were neglected so far. Consequently, their relationship with respect to the magmatism and the geodynamic evolution of the Eastern Pontides remains poorly understood, due to the lack of geochemical and geochronological data.

Recent studies along the Eastern Pontides have provided abundant data and new interpretations for the geodynamic evolution, the regional geology, and the petrogenesis of volcanic and granitic rocks (e.g. Karslı et al., 2012a; Kaygusuz et al., 2013; Okay and Şahintürk, 1997; Okay and Tüysüz, 1999; Topuz et al., 2011). Nevertheless, the timing of the onset of subduction still remains open to question. Some authors suggested that subduction started during the Jurassic or earlier, (e.g. Adamia et al., 1977, 1981; Kazmin et al., 1986), whereas Okay and Şahintürk (1997) proposed that the volcanic arc developed later during the Turonian to MaastrichtianDanian time interval. Therefore, dating the host rocks of porphyry-type mineralizations in the Eastern Pontides will allow us to place constraints on the geodynamic evolution of the belt. Thus, it is important to understand the timing and the nature of the magmatism associated with the various porphyry-type systems in order to constrain the exact relationships between ore-forming and geodynamic processes along the Eastern Pontides magmatic arc. 
In this contribution, we report new $\mathrm{U}-\mathrm{Pb}$ zircon age data of granitic rocks acquired by LA-ICP-MS for the Elbeyli-Ordu, Emeksen-Giresun, Trabzon-Güzelyayla and IspirUlutaş-Erzurum porphyry-type prospects (Fig. 1) and new radiogenic isotope (Sr-Nd$\mathrm{Pb})$ and lithogeochemical data for the Elbeyli-Ordu and Emeksen-Giresun prospects to constrain the age of magmatism, the petrogenesis of the host rocks, and their relationship with the ore-forming events. In addition, we discuss our data within the frame of previously published geochronological, isotopic and lithogeochemical data of the Eastern Pontides, in order to offer a regional synthesis of the timing of magmatism and porphyry-type ore formation along the belt.

\section{Regional Geology and Geodynamic Setting of the Eastern Pontides}

Turkey comprises three main tectonic blocks with distinct stratigraphic and structural features, which are the Anatolide-Tauride block, Kırşehir Massif and the Sakarya block, which includes the Rhodope-Strandja zone, the Istanbul zone and the Eastern Pontides (Fig. 1; Ketin, 1966; Şengör and Yılmaz, 1981; Okay and Tüysüz, 1999). The three main tectonic blocks are bounded by major oceanic suture zones, including: the Izmir-Ankara-Erzincan Suture zone (IAEZ), the Intra-Pontide Suture zone, the Inner-Tauride Suture zone, and the Assyrian-Zagros Suture zone (Fig. 1). The amalgamation of these terranes and the creation of a single landmass occurred during closure of different branches of the Tethyan Oceans from the Late Mesozoic to the Early Cenozoic (e.g. Okay and Tüysüz, 1999; Rolland et al., 2009a; Topuz et al., 2013a; Fig 1, Inset). 
The Elbeyli $\mathrm{Mo} \pm \mathrm{Cu}$, Emeksen Mo, Güzelyayla Cu-Mo, and Ispir-Ulutaş Cu-Mo porphyry-type prospects are located at the Eastern Pontides, which is bounded in the south by the Izmir-Ankara-Erzincan Suture and in the north by the East Black Sea Basin (Fig. 1). To the east, the Eastern Pontides extends into the Lesser Caucasus (Adamia et al., 1977, 1981; Okay and Şahintürk, 1997). The geological evolution of the Eastern Pontides is the result of northward Cretaceous subduction of the Neotethys (e.g. Okay and Şahintürk, 1997; Şengör et al., 1980; Şengör and Yilmaz, 1981; Yılmaz et al., 1997), and Late Cretaceous to early Cenozoic collision to postcollision processes (e.g. Altherr, et al., 2008; Okay, 2008; Topuz et al., 2011). Ore deposits and prospects studied so far in the Eastern Pontides are Cretaceous to Eocene in age and are related to the evolution of the Tethyan Ocean (e.g. Eyüboğlu et al., 2014; Yiğit, 2009).

The basement of the Eastern Pontides comprises Carboniferous high-temperature and low-pressure metamorphic rocks, high-K, I-type granitic rocks, dacite, and Upper Carboniferous sedimentary rocks (Okay and Şahintürk, 1997; Topuz et al., 2007, 2010). Lower to Middle Jurassic volcanic and volcano-sedimentary units, which are crosscut by local gabbro, diorite and I-type granite intrusions, unconformably overlay the pre-Jurassic basement of the Eastern Pontides (Dokuz et al., 2006, 2010; Okay and Şahintürk, 1997; Şen, 2007; Ustaömer and Robertson, 2010). The Jurassic units volcano-sedimentary units are mainly interpreted as a rift-related sequence, which resulted in the opening of the southern branch of Neotethys along a rift zone in the south due to the southward subduction of the Paleotethys (Dokuz et al., 2010; Görür, 1988; Şengör et al., 1980; Şengör and Yılmaz, 1981; Yılmaz et al., 1997). However, this Jurassic magmatism in the Eastern Pontides and its eastern extension in the 
Lesser Caucasus is interpreted also as back-arc magmatism during northward subduction of the Paleotethys (e.g. Rolland et al., 2009b, 2011; Topuz et al., 2013a; Ustaömer and Robertson, 2010; Ustaömer et al., 2012; Fig 2).

During the Late Cretaceous, intense calc-alkaline to tholeiitic, submarine magmatism in the Eastern Pontides was associated with northward subduction of the northern branch of the Neotethys beneath the Eurasian plate. (Akın, 1978; Akıncı, 1984; Eğin et al., 1979; Gedik et al., 1992; Gedikoğlu, 1978; Manetti et al., 1983; Peccerillo and Taylor, 1975). Magmatism began with basaltic and andesitic lava, grading upwards into dacitic and rhyolitic lava interbedded with limestone (Akıncı, 1984; Eğin et al., 1979) and was accompanied by abundant, mainly granitic to granodioritic Cretaceous intrusions (Fig 1).

Shortly after Late Cretaceous arc-related magmatism, closure of the Neotethys led to strong compressional deformation during the Cenozoic, characterized by crustal shortening, thickening and uplift (Okay and Şahintürk, 1997; Yılmaz et al., 1997) (Fig 2). The timing of the transition from subduction to collision has been interpreted to be Paleocene to Early Eocene (e.g. Okay and Şahintürk, 1997; Peccerillo and Taylor, 1975; Şengör and Yılmaz, 1981; Topuz et al., 2011). Middle to Late Eocene magmatic rocks are attributed to a switch of the tectonic regime from compression to extension caused by the opening of the eastern Black Sea Basin (Okay, 2008), although Nikishin et al. (2011) suggest that the eastern Black Sea Basin already opened during the Cenomanian to Coniacian. After a relatively short period of time of extension, the Eastern Pontides was uplifted above the sea level with minor 
volcanism and terrigenous sedimentation at the end of the Eocene (Okay, 2008; Topuz et al., 2011).

\section{Geological Settings of the Porphyry-Type Prospects}

\subsection{The Elbeyli-Ordu Mo \pm Cu prospect}

The newly discovered Elbeyli $\mathrm{Mo} \pm \mathrm{Cu}$ prospect lies within the Kabataş batholith, which is located in the westernmost part of the Eastern Pontides (Fig 1). Mineralization in the Elbeyli prospect is hosted by small monzonite/monzodiorite bodies $\left(<2 \mathrm{~km}^{2}\right)$ and the surrounding Cretaceous volcanic and volcano-sedimentary rocks. The latter consist of andesitic and dacitic lava and pyroclastic rocks. Monzodiorite/monzonite has a pinkish color and a porphyritic texture. It consists of plagioclase, K-feldspar, pyroxene, amphibole, biotite and quartz. Plagioclase phenocrysts are subhedral and normally zoned (core: An51.9-44.3, rim: An26.7-26.5) and some plagioclase crystals are characterized by high albite contents in their rims (Ab70.5-69.6) (Appendix 1).

The Elbeyli prospect consists of a quartz-pyrite \pm chalcopyrite stockwork, and NWstriking quartz-molybdenite-enargite \pm chalcopyrite veins. Stockwork quartzpyrite \pm chalcopyrite mineralization dominates in the Cretaceous volcano-sedimentary rocks, whereas disseminated molybdenite mineralization can be observed around the vein systems crosscutting both volcanic and plutonic rocks. EW- and NE-trending faults cut the plutonic and volcano-sedimentary rocks, and control the quartz-pyrite veins (Delibaş et al., 2014). Late NW-trending faults, dipping $15-70^{\circ}$ to the NE cut the former fault sets and control younger quartz-enargite-molybdenite \pm chalcopyrite veins 
and zunyite-pyrophyllite-bearing alteration assemblages (Delibaş et al., 2015a). The NW-striking vein system at the Elbeyli prospect is characterized by an intermediateto high-sulfidation mineral association including enargite, chalcopyrite, tennantite, tetrahedrite, molybdenite, galena, euhedral pyrite, and minor native bismuth. Enargite and euhedral pyrite are replaced by tennantite and tetrahedrite along rims and fractures. Molybdenite fills the abundant fractures of vein and disseminated pyrite.

\subsection{The Emeksen-Giresun Mo Prospect}

The Emeksen Mo prospect lies within the Emeksen batholith (Doğan, 1980), which is located in the Emeksen-Çakıldağ area within the Eastern Pontides (Fig 1). Reserve or resource data for the Emeksen prospect have not been defined so far, but available data show that average Mo contents of the veins vary between $0.08 \%$ and $2.87 \%$ (MTA, 1984).

The basement of the Emeksen-Çakıldağ area consists of early Mesozoic metamorphic sequences, which are unconformably overlain by Lower to Upper Cretaceous volcanic and volcano-sedimentary rocks (Kamitani et al., 1977). The Late Cretaceous plutonic rocks, which host Mo mineralizations, intrude into the volcanic and volcano-sedimentary sequences of the region. On the basis of geological, mineralogical, and textural characteristics, we have subdivided the plutonic rocks into four main phases, including granodiorite, granite, porphyritic granite and gabbrodiorite. Granodiorite, granite and porphyritic granite have gradational contacts with each other, whereas the gabbro-diorite stocks and dykes of the northern zone have sharp intrusive contacts with granite and older volcanic sequences. In many places, 
granitic rocks contain microgranular, roughly oval dioritic enclaves, which are finegrained, medium to dark grey, and have sharp contacts with their hosts.

The porphyritic granite is the predominant intrusive unit of the region and it consists of euhedral to subhedral normally zoned plagioclase (core: An38.06-35.82, rim: An28.4920.27), quartz, subhedral K-feldspar (core: Or84.8, rim Or90.2) (Appendix 2), subhedral amphibole and biotite. Apatite, zircon, titanite and rutile are the most common accessory minerals and epidote, chlorite and sericite are alteration products of the main mineral association. The other major plutonic phase of the Emeksen area is an epi-granular, coarse-grained granite. The granite is exposed in the western part of the area and it is mineralogically very similar to that of the porphyritic granite, except that the latter has a more pronounced porphyritic texture. Furthermore, plagioclase phenocrysts display both normal (core: An76.6-65.5, rim: An31.7-13.7) and slight reverse zoning, with low An cores (An 51.4-50.3) surrounded by relatively high An rims (An67.553.6) (Appendix 2).

The granodiorite is medium-grained and grey to dark grey in color. It has predominantly an epi-granular texture, and amphibole, biotite, plagioclase, quartz and K-feldspar are the main mineral phases. The secondary minerals consisting of sericite, chlorite, calcite and as well as muscovite are very common within the granodiorite because of the intense sericitic alteration. Plagioclase crystals display normal (core: An52.3-48.0, rim: An33.4-31.5) and reverse zoning (core: An48.18-38.75, inner rim: An49.5-43.6, outer rim: An34.1-32.5) (Appendix 2). 
Mo mineralization in the Emeksen area is related to stockwork and NW-, and NSstriking vertical/sub-vertical quartz veins crosscutting the granodiorite, the granite and the porphyritic granite (Delibaş et al., 2014; 2015b). Sericitic alteration consists of muscovite and biotite is the dominant alteration around veins.

\subsection{The Güzelyayla-Trabzon Cu-Mo prospect}

The Güzelyayla Cu-Mo prospect is located about $50 \mathrm{~km}$ south of the city center of Trabzon (Fig 1). Exploration campaigns allowed to define $186.2 \mathrm{Mt}$ at $0.3 \% \mathrm{Cu}$ equivalent and $0.002-0.021 \%$ Mo of total proven and probable reserves according to Er et al. (1992) and Güner and Güç (1990).

The known stratigraphy in the Güzelyayla prospect is entirely composed of Upper Cretaceous volcanic rocks with intercalations of siltstone-mudstone and limestone, and all volcanic- and volcano-sedimentary units are crosscut by a porphyritic granite, a dacite porphyry, and quartz porphyry dykes (Çınar and Yazıcı, 1985; Nebioğlu, 1983).

A porphyritic granite is the largest intrusive body in the mapped area of the Güzelyayla prospect and is exposed in the southern part of the area. It is pinkish to grey in color and it has a dominantly porphyritic texture. Plagioclase and quartz are the common phenocrysts within the medium-grained and epi-granular groundmass. The porphyritic granite is crosscut by the dacite porphyry, which hosts the Cu-Mo mineralization. It is mostly composed of quartz, plagioclase, K-feldspar, biotite and minor amphibole. Magnetite, hematite and rutile are present in nearly every sample. Apatite and zircon are common accessory minerals of the dacite porphyry. 
The Güzelyayla Cu-Mo prospect consists of two types of mineralization known as stockwork-type and dissemination. Stockwork-type quartz veins crosscutting the dacite porphyry and Cretaceous volcanic rocks are typically rich in chalcopyrite, pyrite, pyrrhotite, rutile and minor molybdenite, whereas disseminated mineralization in dacite porphyry is characterized by chalcopyrite, magnetite and pyrite. On the other hand, molybdenite is mainly enriched in the late stage, 0.1 to $4 \mathrm{~cm}$ thick quartz veins cutting dacite porphyry and Cretaceous volcanic rocks (Delibaş et al., 2014).

\subsection{The Ispir-Ulutaş-Erzurum Cu-Mo prospect}

The Ulutaş Cu-Mo prospect lies within the Ispir batholith (Fig 1). Based on drill-hole data, the total reserves were estimated at $73.6 \mathrm{Mt}$ at a grade of $0.31 \% \mathrm{Cu}$ and 0.022\% Mo (Giles, 1973; Soylu, 1999; Yiğit, 2009).

Porphyry type Cu-Mo mineralization at the Ulutaş prospect is hosted by granite porphyry and quartz porphyry of the Ispir batholith, which is a calc-alkaline multiphase plutonic complex varying from granite through quartz diorite to syeno-diorite. A granodiorite phase of the batholith exposed $1 \mathrm{~km}$ east of the prospect yielded a K-Ar age of $132 \pm 5 \mathrm{Ma}$ (Giles, 1973).

The oldest units exposed in the northwestern part of the Ulutaş area are PaleozoicLower Mesozoic metamorphic rocks. The metamorphic basement is covered by strongly folded, weakly metamorphosed Cretaceous lava flows of dacitic to rhyolitic composition and pyroclastic rocks with intercalations of laminated mudstone, and shale (Giles, 1973; Taylor and Fryer, 1980). The basement units and volcanosedimentary sequence are intruded by Ulutaş intrusions that form an erosion window 
in the Eocene volcanic- volcano-sedimentary rocks, comprising andesitic to basaltic lava, tuff and agglomerate with marl, conglomerate, sandstone and limestone intercalations (Giles, 1973; Taylor and Frey, 1980).

A granite porphyry hosting Cu-Mo mineralization exposed in the northern part of the area represents the largest intrusive unit in the region. It is characterized by a pronounced porphyritic texture at the outcrop scale. Central parts of the granite porphyry are characterized by intrusions of NE-trending, steeply dipping quartz porphyry dykes or stocks, with a porphyritic texture with phenocrysts of embayed quartz and a fine-grained groundmass of quartz and highly sericitized plagioclase. Both granite porphyry and quartz porphyry are crosscut by dioritic, andesitic dykes hosting pyrite-chalcopyrite veinlets (1 to $2 \mathrm{~mm}$ ), The granite porphyry contains microgranular, roughly oval medium to dark grey dioritic enclaves, which have sharp contacts with their host. All units are overlain by Pleistocene to recent glacial debris and alluvial sediments (Giles, 1973).

Porphyry-type mineralization in the Ulutaş area consists of stockwork veins and NWstriking quartz veins, with disseminated chalcopyrite along the vein systems, and molybdenite within the 1-2cm thick quartz veins (Soylu, 1999).

\section{Results}

\subsection{Whole-rock geochemistry of intrusive rocks}

The analytical techniques used in the present study are summarized in Appendix 3 and the major and trace element data of the Elbeyli and Emeksen intrusive rocks are presented in Appendix 4 and 5. Geochemical data for the Güzelyayla and Ulutaş 
intrusions were taken from Yalçınalp (1992) and Taylor and Frey (1980), respectively. The $\mathrm{Zr} / \mathrm{TiO}_{2}$ vs. $\mathrm{Nb} / \mathrm{Y}$ diagram (Winchester and Floyd, 1977) is used to classify intrusive rocks from Elbeyli and Emeksen (Fig 3a), because of the effects of hydrothermal alteration, and the classification terminology of the plutonic rocks are taken from Middlemost (1985).

Plutonic rocks from Elbeyli range in composition from monzonite to diorite with $\mathrm{SiO}_{2}$ contents varying from 58 to 63.5 wt.\%, and the Emeksen plutonic rocks range in composition from granodiorite to monzonite with $\mathrm{SiO}_{2}$ contents varying from 63.5 to 75 wt.\%, whereas the Güzelyayla samples are granodioritic and the Ispir-Ulutaş samples are granitic in composition. Dioritic rocks crosscutting the granitic rocks at Emeksen are dioritic/gabbroic in composition (Fig 3a). The Elbeyli samples have higher $\mathrm{Al}_{2} \mathrm{O}_{3}$ (average: 16 wt.\%), $\mathrm{FeO}_{\mathrm{t}}(6.5 \mathrm{wt} . \%), \mathrm{MgO}$ (average: 2.2 wt.\%) and $\mathrm{CaO}$ (average: 4 wt.\%) contents when compared to the Emeksen granitic and granodioritic samples (average: 15 wt.\%, 4 wt.\%, 1.2 wt.\% and 2.3 wt. \%, respectively) and the $\mathrm{K}_{2} \mathrm{O} / \mathrm{Na}_{2} \mathrm{O}$ ratio for the Elbeyli and Emeksen samples vary between 1.5 to 2.5 and 1 to 2, respectively. Diorite samples of the Emeksen prospect, on the other hand, have high $\mathrm{FeO}_{\mathrm{t}}$ (average: 11.5 wt.\%), $\mathrm{MgO}$ (average: 5.3 wt.\%) and $\mathrm{CaO}$ (average: 9.5 wt.\%) and low contents of $\mathrm{SiO}_{2}$ (average: 53.2 wt.\%), $\mathrm{Na}_{2} \mathrm{O}$ (average: 2.5 wt.\%) and $\mathrm{K}_{2} \mathrm{O}$ (average: 0.3 wt.\%). Guzelyayla and Ispir- Ulutaş samples and also granodioritic and granitic rocks from the Emeksen prospect are all sub-alkaline in nature, whereas the Elbeyli monzonitic samples straddle the boundary between alkaline to subalkaline series in the total alkali $\left(\mathrm{Na}_{2} \mathrm{O}+\mathrm{K}_{2} \mathrm{O}\right)$ vs. $\mathrm{SiO}_{2}$ diagram (Fig 3b). In the AFM diagram (Fig. 3c), Elbeyli and Emeksen granitic and granodioritic rocks and also the Güzelyayla and Ispir-Ulutaş samples plot in the calc-alkaline field, whereas diorite 
samples from Elbeyli haves a tholeiitic character. However, there is a clear transition from calc-alkaline to tholeiitic compositions for all rock series (Fig 3c). Samples from Elbeyli exhibit a shoshonitic compositional trend, while Emeksen granitic and granodioritic samples mainly belong to the high-K calc-alkaline to shoshonitic series. On the other hand, Güzelyayla and Ispir-Ulutaş samples range in composition from calc-alkaline to high-K calc-alkaline (Fig 3d).

Binary plots of Elbeyli and Emeksen samples for most of the major elements show a good correlation with $\mathrm{SiO}_{2}$ (Fig 4). $\mathrm{TiO}_{2}, \mathrm{Al}_{2} \mathrm{O}_{3}, \mathrm{MgO}, \mathrm{CaO}$ and $\mathrm{FeO}$ t contents decrease with increasing $\mathrm{SiO}_{2}$, and $\mathrm{K}_{2} \mathrm{O}$ and $\mathrm{Na}_{2} \mathrm{O}$ concentrations slightly increase with increasing $\mathrm{SiO}_{2}$ (Fig 4). Although trace element variations of the Elbeyli and Emeksen samples show some scattering, $\mathrm{Ni}$ and $\mathrm{V}$ contents decrease with increasing $\mathrm{SiO}_{2}$. $\mathrm{La}$ and $\mathrm{Ba}$ display a slight positive correlation with increasing $\mathrm{SiO}_{2}$ for the Emeksen samples (Fig 4). The Elbeyli rocks have higher $\mathrm{Ni}$ and $\mathrm{V}$ contents ranging from 9 to $16 \mathrm{ppm}$ (average $8.5 \mathrm{ppm}$ ) and 106 to $174 \mathrm{ppm}$ (average 122 ppm), respectively, whereas the Emeksen granite and granodiorite samples have variable and lower $\mathrm{Ni}$ (ranging from 3 to $17 \mathrm{ppm}$; average: $5 \mathrm{ppm}$ ) and $\mathrm{V}$ (ranging from 18 to 150 ppm, average: 61) contents. In addition, both Elbeyli and Emeksen samples have low to moderate Sr contents (for Elbeyli average: $363 \mathrm{ppm}$; for Emeksen granodioritic and granitic sample average: $233 \mathrm{ppm}$ ), compared to adakitic rocks. However, they have relatively high $\mathrm{Y}$ (Elbeyli average: 21 ppm; Emeksen average: $20 \mathrm{ppm}$ ) and $\mathrm{Yb}$ concentrations (Elbeyli average: $1.8 \mathrm{ppm}$; Emeksen average: $2 \mathrm{ppm}$ ) and explain low to moderate $\mathrm{Sr} / \mathrm{Y}$ and $\mathrm{La} / \mathrm{Yb}$ ratios for both Elbeyli and Emeksen samples. Therefore, in the Sr/Y vs. Y diagram (Fig 5a), the Elbeyli and Emeksen granite and granodiorite samples plot within the normal volcanic-arc field, 
whereas the Emeksen porphyritic granite and Güzelyayla dacite porphyry samples straddle the boundary between the adakitic and volcanic-arc fields. Similarly some samples of the Guzelyayla prospect plot in both adakitic and calc-alkaline fields on the $\mathrm{Sr} / \mathrm{Y}$ vs. $\mathrm{SiO}_{2}$ diagram (Fig $\mathbf{5 b}$ ). Furthermore, $\mathrm{La} / \mathrm{Yb}$ ratios remain constant for variable $\mathrm{SiO}_{2}$ contents of the Emeksen (granitic and granodioritic) and Elbeyli samples (Fig 5c).

The Elbeyli, Emeksen, Güzelyayla and Ispir-Ulutaş samples have nearly similar mantle-normalized spider patterns and they display subduction-related features (Figs 6a-d), including high concentrations of large-ion lithophile elements (LILE), low contents of high field strength elements (HFSE), and negative $\mathrm{Nb}$ and Ti and positive $\mathrm{Pb}, \mathrm{K}$ and $\mathrm{U}$ anomalies. The Emeksen granodioritic and granitic samples show moderate negative $\mathrm{Eu}$ anomalies $\left(\mathrm{Eu} / \mathrm{Eu}^{*}=0.5-0.9\right)$ and variable light rare earth element (LREE) enrichments $\left((\mathrm{La} / \mathrm{Yb})_{\mathrm{N}}=7-13.5\right)$ and more pronounced depleted medium rare earth element (MREE) patterns in chondrite-normalized REE diagrams (Fig 7), whereas the Elbeyli samples are characterized by weak negative Eu anomalies $\left(E u / E u^{*}=0.7-0.9\right)$ with $(\mathrm{La} / \mathrm{Yb})_{\mathrm{N}}$ of 8.0-10, when compared to the Emeksen granodioritic and granitic samples (Fig 7). Diorite samples from Emeksen have highly variable LREE enrichments with $(\mathrm{La} / \mathrm{Yb})_{N}$ of $0.8-2$ and have either positive or negative Eu anomalies with $\left(\mathrm{Eu} / \mathrm{Eu}^{*}\right)$ values ranging from 0.7 to 1.2 (Fig 7c).

\subsection{U-Pb Zircon Geochronology}

Abundant geochronological data have been obtained in recent years for Upper Cretaceous to Paleocene granitoids related to Neotethys subduction and collision in the Eastern Pontides (e.g. Boztuğ et al., 2004; Boztuğ and Harlavan, 2008; Karslı et 
al., 2010; Kaygusuz et al., 2008, 2009, 2013, 2014). However, no reliable geochronological data have been produced so far for granitic rocks, which host porphyry type prospects in the region. Therefore, seven plutonic rock samples were chosen from the Elbeyli (OFA-1), Emeksen (GE-1, GE-2, and GE-4), Güzelyayla (TMG-1) and Ispir-Ulutaş areas (Ei-1 and Ei-3) for U-Pb dating by LA-ICP-MS. The analytical techniques used in the present study are summarized in Appendix 1, the results are listed in Appendix 6 to 12, and ${ }^{206} \mathrm{~Pb} /{ }^{238} \mathrm{U}$ Concordia plots are shown in Figures 8 and 9.

Sixteen spots were analyzed on zircon grains separated from a monzonite/monzodiorite from the Elbeyli prospect (sample OFA 1, Appendix 6), eight of these were excluded from age calculation due to their strong discordance and eight concordant analyses yielded a weighted mean age of $77.0 \pm 1.3 \mathrm{Ma}$ with a MSDW of 2.2 (Fig 8a). Three rock samples were collected at the Emeksen prospect, including a porphyry granite (sample GE-1), a granodiorite (sample GE-2), a granite (sample GE-4). Fifteen spots from magmatic zircons of the porphyry granite (GE-1, Appendix 7) and from the granodiorite (GE-2, Appendix 8) yielded weighted mean ages, respectively, of $77.7 \pm 0.5 \mathrm{Ma}$ with a MSWD of 2.7 (Fig $8 \mathbf{b}$ ) and $78.7 \pm 0.5 \mathrm{Ma}$ with a MSWD of 2.5 (Fig 8c). Analyses of ten spots in zircons from the granite sample (GE-4, Appendix 9) from the Emeksen prospect yielded a weighted mean age of $78.5 \pm 0.8$ Ma with a MSWD of 1.6 (Fig 8d). For sample TMG-1 from the Güzelyayla prospect, sixteen spot were analyzed on zircon grains (Appendix 10). Five of these were excluded because they were interpreted as xenocrystic cores yielding a weighted mean age of $287 \pm 7 \mathrm{Ma}$ (Fig 9a, inset). Eleven concordant analyses gave a weighted mean age of $81.4 \pm 1.1$ Ma with a MSWD of 4.4 (Fig 9a). At 
the Ispir-Ulutaş prospect, eleven spots on zircons from quartz porphyry (sample Ei-1, Appendix 11) gave a weighted mean age of $131.1 \pm 0.9$ Ma with a MSWD of 0.92 (Fig 9b), and twenty spots on magmatic zircons from the granitic wall rock of the mineralization (sample Ei-3, Appendix 12) yielded a weighted mean age of $132.9 \pm 0.6$ Ma with a MSWD of 1.5 (Fig 9c).

\subsection{Whole-rock $\mathrm{Sr}, \mathrm{Nd}$ and $\mathrm{Pb}$ isotopic compositions}

The age-corrected $(80 \mathrm{Ma})$ initial $\mathrm{Sr}, \mathrm{Nd}$ and $\mathrm{Pb}$ isotope data for whole-rock samples from Elbeyli and Emeksen are presented in Appendix 13 and 14, and the analytical techniques used in the present study are summarized in Appendix 3.

Initial $\varepsilon N d(T)$ values of the Elbeyli monzonitic samples range from 0.7 to 1.3 and ${ }^{87} \mathrm{Sr} /{ }^{86} \mathrm{Sr}_{i}$ isotope ratios vary from 0.70478 to 0.70482 . The initial $\mathrm{Nd}$ and $\mathrm{Sr}$ isotopic compositions of the granitic and granodioritic host rocks from the Emeksen prospect are characterized by a wide range of $\varepsilon N d(T)$ values from -4.7 to -2.0 and ${ }^{87} \mathrm{Sr} /{ }^{86} \mathrm{Sr}_{\mathrm{i}}$ ratios from 0.70567 to 0.70780 , whereas diorite samples from Emeksen have higher $\varepsilon N d(T)$ values of 3.3 to 4.8 and a very narrow range of ${ }^{87} \mathrm{Sr} /{ }^{86} \mathrm{Sr}$ ratios between 0.70466 and $0.70500 .{ }^{143} \mathrm{Nd} /{ }^{144} \mathrm{Ndi}$ and ${ }^{87} \mathrm{Sr} /{ }^{86} \mathrm{Sr}_{i}$ of the Emeksen granitic and granodioritic samples display a slight negative correlation, and overlap with the composition of Upper Cretaceous arc-related granitoids of the Eastern Pontides (Fig 10a). The Elbeyli monzonite and Emeksen diorite yielded higher ${ }^{143} \mathrm{Nd} /{ }^{144} \mathrm{Ndi}$ ratios and lower ${ }^{87} \mathrm{Sr} /{ }^{86} \mathrm{~S} r_{i}$ ratios when compared to the Emeksen granite and granodiorite, and Upper Cretaceous arc-related granitoids of the Eastern Pontides (Fig 10a). The ${ }^{87} \mathrm{Sr}^{86} \mathrm{Sr}_{\mathrm{i}}$ ratios of the granite and the granodiorite from Emeksen are inversely correlated with $\mathrm{SiO}_{2}$ contents (Fig. 10b), whereas the ${ }^{143} \mathrm{Nd} /{ }^{144} \mathrm{Nd}$ ratios display a 
slight positive correlation with $\mathrm{SiO}_{2}$ contents (Fig 10c). The ${ }^{87} \mathrm{Sr} /{ }^{86} \mathrm{Sr}_{i}$ and ${ }^{143} \mathrm{Nd} /{ }^{144} \mathrm{Ndi}$ ratios of the Elbeyli monzonite and the Emeksen diorite remain nearly constant regardless of the $\mathrm{SiO}_{2}$ content (Figs 10b-c).

Except diorite, the Emeksen samples have highly variable and the most radiogenic ${ }^{206} \mathrm{~Pb} / 204 \mathrm{Pbi}$ (18.681-18.831), ${ }^{207} \mathrm{~Pb} / 204 \mathrm{Pbi}$ (15.662-15.671) and ${ }^{208} \mathrm{~Pb} / 204 \mathrm{Pbi}$ (38.69138.789) ratios. By contrast, diorite from the Emeksen prospect has lower lead isotope ratios $\left({ }^{206} \mathrm{~Pb} /{ }^{204} \mathrm{Pbi}=18.338-18.686,{ }^{207} \mathrm{~Pb} /{ }^{204} \mathrm{Pbi}=15.628-15.661,{ }^{208} \mathrm{~Pb} /{ }^{204} \mathrm{Pbi}=\right.$ 38.618-38.774), as well as two rock samples from Elbeyli $\left({ }^{206} \mathrm{~Pb} / 204 \mathrm{~Pb}\right.$ of 18.598 and $18.623,{ }^{207} \mathrm{~Pb} / 204 \mathrm{~Pb}$ of 15.653 and $15.657,{ }^{208} \mathrm{~Pb} / 204 \mathrm{Pbi}$ of 38.619 and 38.649 ) (see Appendix 14). . In the ${ }^{206} \mathrm{~Pb} / 204 \mathrm{Pbi}$ vs ${ }^{207} \mathrm{~Pb} / 204 \mathrm{Pbi}$ space (Figure 10d), all samples show a slight positive correlation and plot between the Zartman and Doe (1981) upper crust and orogen evolution lines.

\section{Discussion}

5.1. Fractional Crystallization with Crustal Contamination and Magma Mixing/Mingling

The geochemical analyses indicate that the Elbeyli, Emeksen, Güzelyayla and IspirUlutaş granitic and monzonitic rocks share many features, such as LILE enrichment, negative $\mathrm{Nb}$ and $\mathrm{Ti}$ anomalies, and LREE enrichment over HREE, and the ages of the host rocks of both prospects agree well with the age of other arc-related granitoids of the Eastern Pontides (e.g. Karslı et al., 2010; Kaygusuz and Şen, 2011; Kaygusuz et al., 2014). However, the Elbeyli and Emeksen host rocks have distinct trace element and isotopic compositions, which imply different petrogeneric 
processes during their evolution, including crustal contamination, partial melting and magma mixing/mingling.

Decreasing $\mathrm{MgO}, \mathrm{FeO}_{\mathrm{t}}, \mathrm{TiO}_{2}, \mathrm{CaO}, \mathrm{P}_{2} \mathrm{O}_{5}, \mathrm{Ni}$ and $\mathrm{V}$ concentrations correlating with increasing $\mathrm{SiO}_{2}$ contents in each rock groups are consistent with fractional crystallization (Fig 4), which is supported by phenocryst assemblages of plagioclase, amphibole, clinopyroxene and accessory apatite and Fe-Ti oxides in both the Elbeyli and Emeksen samples. The main differences are the absence of correlation of $\mathrm{K}_{2} \mathrm{O}$ and $\mathrm{Ba}$ with $\mathrm{SiO}_{2}$ in the Elbeyli samples, in contrast to the Emeksen samples, which reveal a positive correlation among these elements (Fig 4). This suggests that Kfeldspar fractionation was negligible during the early stages of the petrogenesis at Emeksen. The strong enrichment in $\mathrm{Ba}$ (see Appendix 5) at Emeksen cannot be explained by fractional crystallization only.

REE ratios can help in revealing fractionation of garnet and/or amphibole during fractional crystallization (Davidson et al., 2007; Macpherson et al., 2006). Low to moderate, and nearly constant $\mathrm{La} / \mathrm{Yb}$ ratios of 13.2 at Elbeyli and 14.6 at Emeksen (Fig 5c), and decreasing $\mathrm{Dy} / \mathrm{Yb}$ ratios with increasing $\mathrm{SiO}_{2}$ (Fig 11a) are inconsistent with garnet fractionation and only reveal amphibole fractionation. This conclusion is also supported by the concave-shaped trend of MREEs to HREEs in the chondritenormalized plots (Figs $7 \mathrm{a}-\mathrm{b}$ ), and decreasing $\mathrm{Gd} / \mathrm{Yb}$ ratios with increasing $\mathrm{SiO}_{2}$ contents for both groups (not shown). In addition, the Elbeyli monzonite samples display a more marked increase in $\mathrm{Zr} / \mathrm{Sm}$ with increasing $\mathrm{SiO}_{2}$ (Fig 11b), which reflects a dominant amphibole fractionation during their magmatic evolution (e.g. Davidson et al., 2007; Hora et al., 2009; Macpherson et al., 2006). Decreasing CaO, 
and $\mathrm{Al}_{2} \mathrm{O}_{3}$ concentrations (Fig 4), and $\mathrm{Sr} / \mathrm{Y}$ ratios (Fig 5b) with increasing $\mathrm{SiO}_{2}$ contents, and negative Eu anomalies (Figs $7 \mathbf{a}-\mathbf{b}$ ) are consistent with plagioclase fractionation at relatively shallow crustal levels in the absence of high-pressure amphibole fractionation, therefore leading to a normal arc trend with low $\mathrm{Sr} / \mathrm{Y}$ ratios (average 17.2 for Elbeyli and 12 for Emeksen samples) (e.g. Castillo et al.,1999; Chiaradia, 2009a; Davidson et al., 2007; Hora et al., 2009; Macpherson et al., 2006; Rodriguez et al., 2007). Additionally, the Elbeyli samples display a sharp decrease in $\mathrm{Na}_{2} \mathrm{O}$ and $\mathrm{Sr}$ (not shown) at constant $\mathrm{SiO}_{2}$ concentrations of $\sim 56 \%$. This pattern can be explained by sudden Na-rich plagioclase crystallization, which may have taken place after the pyroxene-Ca-plagioclase-amphibole fractionation during the emplacement of the monzonitic/granitic body.

Marked depletions of $\mathrm{Nb}$ and $\mathrm{Ti}$, and enrichments in $\mathrm{U}, \mathrm{Th}, \mathrm{K}$ and $\mathrm{Pb}$ are not only indicative of arc-related magmatism, but can also be related to crustal contamination/assimilation processes (Whalen et al., 1996). DePaolo (1981) pointed out that crustal contamination or assimilation affects the isotopic composition of magmas and may explain negative $\varepsilon N d(T)$ values as well as increasing ${ }^{87} \mathrm{Sr} /{ }^{86} \mathrm{~S} r_{i}$ ratios with increasing $\mathrm{SiO}_{2}$ contents. In this study, high $\mathrm{K}_{2} \mathrm{O} / \mathrm{TiO}_{2}$ and $\mathrm{K}_{2} \mathrm{O} / \mathrm{P}_{2} \mathrm{O}_{5}$ ratios (average 15 and 49, respectively) in the Emeksen granitic rocks and higher $\mathrm{Th} / \mathrm{Yb}$ (average 12) and lower $\mathrm{Nb} / \mathrm{Th}$ (average 0.4 ) ratios with marked Th enrichment in comparison to Elbeyli monzonitic rocks in primitive mantle-normalized plots (Fig. 6) indicate that crustal contamination could have played a role during their evolution. Also, negative $\varepsilon N d(T)$ values, highly variable ${ }^{87} \mathrm{Sr} /{ }^{86} \mathrm{Sr}_{i}$ ratios between 0.70567 to 0.70780 (Fig 10a), and high radiogenic $\mathrm{Pb}$ isotopic compositions (Appendix 14) of the Emeksen rocks support a significant role of crustal contamination. 
Conversely, both granitic and granodioritic samples from Emeksen are characterized by decreasing ${ }^{87} \mathrm{Sr} /{ }^{86} \mathrm{Sr}$ and increasing ${ }^{143} \mathrm{Nd} /{ }^{144} \mathrm{Ndi}$ ratios with magmatic evolution, which support mixing with high $\varepsilon \mathrm{Nd}(\mathrm{T})$ and low ${ }^{87} \mathrm{Sr} /{ }^{86} \mathrm{Sr}$ magmas. Such features can be explained by magma mixing/mingling processes (Figs 10b-c). Furthermore, decreasing $\varepsilon N d(T)$ values with increasing LREEs/MREEs (La/Gd) ratios, and increasing $\varepsilon N d(T)$ values with increasing MREEs/HREEs $(\mathrm{Gd} / \mathrm{Yb})$ ratios suggest that amphibole fractionation was accompanied by assimilation or mixing with low $\varepsilon N d(T)$ material/magma (DePaolo, 1981; Chiaradia et al. 2009b). However, increasing $\varepsilon N d(T)$ with decreasing $G d / Y b$ in the Emeksen samples also suggests mixing with a high $\varepsilon N d(T)$ magma (Fig 11C). Moreover, evidence for mixing/mingling processes include the presence of abundant mafic micro-granular enclaves (MMEs), disequilibrium textures, such as amphibole and biotite inclusions arranged along the crystallographic directions of the host plagioclase, as well as normal (e.g. core: An76.6-65.5, rim: $A n_{31.7-13.7)}$ and reverse zoned plagioclase crystals (e.g. core: An51.450.3, rim: An67.5-53.6) in the Emeksen granitic samples (see Appendix 2). Xenocrystic cores $(287.1 \pm 7 \mathrm{Ma})$ of zircon grains of the Güzelyayla dacite porphyry (Fig 9a, Inset) and common microgranular enclaves in the granite porphyry of the Ispir-Ulutaş prospect also support crustal contamination and magma mixing/mingling processes. All of these characteristics, therefore, indicate the involvement of crustal components and magma mixing/mingling process during ascent of magmas to the surface.

The Elbeyli samples, on the other hand, have relatively lower $\mathrm{Th} / \mathrm{Yb}$ (average 9.8) and higher $\mathrm{Nb} / \mathrm{Th}$ (average 0.7 ) ratios, and they have nearly constant trends of ${ }^{87} \mathrm{Sr} /{ }^{86} \mathrm{Sr}_{\mathrm{i}}$ and ${ }^{143} \mathrm{Nd} /{ }^{144} \mathrm{Ndi}$ ratios with increasing $\mathrm{SiO}_{2}$ contents (Figs 10b-c), documenting limited crustal contamination. 


\subsection{Nature of Magmatism in the Elbeyli and Emeksen prospects}

The Upper Cretaceous high-K calc-alkaline to shoshonitic host rocks of the Elbeyli and Emeksen prospects display geochemical characteristics of arc magmas with marked depletions in $\mathrm{Nb}$ and $\mathrm{Ti}$, and enrichments in $\mathrm{U}, \mathrm{Th}, \mathrm{K}$ and $\mathrm{Pb}$, with steep REE patterns (Figs 6 and 7). As discussed in the previous section, fractional crystallization with weak crustal contamination has played an important role in the case of the Elbeyli magmas, whereas the Emeksen magmatism was dominated by fractional crystallization with significant crustal contamination and magma mingling/mixing processes.

The shoshonitic nature of the Elbeyli samples, together with positive $\varepsilon N d(T)$ values of +0.7 to +1.3 , low ${ }^{87} \mathrm{Sr} / 86 \mathrm{Sr}$ ratios of $0.70478-0.70482$, and high $\mathrm{Rb}$ (average 189 ppm), Ba (average $440 \mathrm{ppm}$ ) and $\mathrm{U}$ (average $7.6 \mathrm{ppm}$ ) contents speak against crustal contamination and fractional crystallization processes. These geochemical features are tightly linked to the source region rather than to fractional crystallization or crustal contamination processes. On the contrary, highly variable ${ }^{87} \mathrm{Sr} /{ }^{86} \mathrm{Sr}$ ratios between 0.70567 to $0.70780, \varepsilon N d(T)$ values of -2.0 to -4.7 , and high radiogenic $\mathrm{Pb}$ isotopic signatures of the Emeksen samples (Fig 10d, Appendix 13-14), accompanied by high and variable $\mathrm{K}_{2} \mathrm{O}$ and $\mathrm{Ba}$ contents reflect crustal contamination and magma mixing processes rather than the source region.

Subduction-related fluids are enriched in $\mathrm{Ba}, \mathrm{Rb}, \mathrm{U}$ and $\mathrm{Pb}$, and depleted in $\mathrm{Th}, \mathrm{Nb}$, Ta and Ti (Pearce, 1983). Furthermore, shoshonitic rocks forming in an arc setting display LILE and LREE enrichments with $\mathrm{Ta}, \mathrm{Ti}$, and $\mathrm{Nb}$ depletion (e.g. Muller and Groves, 1995). Although, Roberts and Clemens (1993) indicated that high-K, I-type 
magmas can be produced by partial melting of meta-igneous rocks in the crust, some studies have shown that shoshonitic and K-rich mafic rocks in continental arcs could also be derived from K-rich metasomatised lithospheric mantle, and shoshonitic magmas are sourced from more strongly metasomatised magma reservoirs than those producing arc tholeiites and calc-alkaline magmas (e.g. Doglioni et al., 1999; Meen and Eggler, 1987; Wallace and Carmichal, 1992). Additionally, Conticelli et al. (2002) stated that the heterogeneity of metasomatised mantle sourcing arc magmas can explain variable degrees of K-enrichment in subduction zones. According to Foley (1992), interaction between metasomatic fluids with a lithospheric mantle source can produce vein networks of clinopyroxene/amphibole/phlogopite within the lithospheric mantle. In addition, mantle metasomatism can lead to the formation of hydrous phlogopite and/or amphibole (Beccaluva et al., 2004), and melts in equilibrium with phlogopite have relatively high $\mathrm{Rb} / \mathrm{Sr}(>0.1)$ and low $\mathrm{Ba} / \mathrm{Rb}(<20)$ ratios (Furham and Graham, 1999).

We use the $T h / Y b$ vs. Ta/Yb plot of Pearce (1983) to constrain the source region of the magmas, which produced the host rocks of the Elbeyli and Emeksen prospects (Fig 11d). The monzonitic and granitic samples from the Elbeyli and Emeksen areas form trends that are parallel to the enriched mantle source, whereas gabbroic rocks of the Emeksen area are distributed along the depleted mantle array in the $\mathrm{Th} / \mathrm{Yb}$ vs. $\mathrm{Ta} / \mathrm{Yb}$ plot. As discussed in the previous section, high $\mathrm{Th} / \mathrm{Yb}$ ratios of the Emeksen samples indicate crustal inputs, whereas Th-enrichments (high $\mathrm{Th} / \mathrm{Yb}$ ) of the Elbeyli samples can be attributed to upwelling of a hot asthenospheric mantle, rather than to crustal contamination, since $\varepsilon N d(T)$ values of +0.7 to +1.3 of the Elbeyli samples are inconsistent with significant contamination from crustal material. Additionally, the 
Elbeyli and Emeksen samples have relatively high $\mathrm{Rb} / \mathrm{Sr}$ (average of 0.5 and 0.7 , respectively) and relatively low $\mathrm{Ba} / \mathrm{Rb}$ (average of 2.4 and 5.5 , respectively) ratios, suggesting the presence of phlogopite in equilibrium with a metasomatised mantle source.

The lower crust is mafic in composition and is strongly depleted in $\mathrm{K}$ and other highly incompatible elements relative to shallower levels of the crust (Rudnick and Gao, 2003). Therefore, the lower content of $\mathrm{K}_{2} \mathrm{O}$ (average $0.3 \mathrm{wt} . \%$ ) and of other incompatible (e.g. Sr, Ba) elements of the Emeksen gabbroic rocks is also consistent with a mafic lower crust, rather than a lithospheric mantle source.

The high-K calc-alkaline rocks of Emeksen and the shoshonitic rocks of Elbeyli fall along the partial melting line and fractional crystallization line, respectively, in the $\mathrm{Nb}$ vs. $\mathrm{Ba} / \mathrm{Nb}$ plot (Fig 12a), which indicates that they were produced by different magmatic evolution trends. Additionally, the most evolved samples from Elbeyli, with a $\mathrm{SiO}_{2}$ content of $63.6 \mathrm{wt} . \%$, and the high- $\mathrm{K}$ calc-alkaline Emeksen rocks fall along the fluid-related enrichment array in the $\mathrm{Rb} / \mathrm{Y}$ vs. $\mathrm{Nb} / \mathrm{Y}$ plot (Fig 12b), whereas the more primitive samples from Elbeyli, with a $\mathrm{SiO}_{2}$ content of 57.6 wt.\%, lie along the melt enrichment trend (Fig 12b), with an inflection at a $\mathrm{Nb} / \mathrm{Y}$ ratio of around 0.6, which may indicate that the magmas of the Elbeyli monzonitic rocks experienced a more intense/longer exchange with an enriched lithospheric mantle than the magmas related to the Emeksen rocks. Their relatively high $\mathrm{Ni}$ and $\mathrm{V}$ contents, with relatively high Mg\# (33-44) and positive $\varepsilon N d(T)$ values also support this interpretation (see Appendix 13). In addition, the depth of the mantle source and the degree of partial melting can be revealed by the La/Sm vs. Sm/Yb plot (Ernst and Buchan, 2003), with 
increasing $\mathrm{Sm} / \mathrm{Yb}$ ratios reflecting the pressure-dependent changes from clinopyroxene to garnet in the mineral residue (Kay and Kay, 1991) (Fig 12c). In the Elbeyli and Emeksen samples, La/Sm ratio decrease progressively with increasing $\mathrm{Sm} / \mathrm{Yb}$ ratios, and increasing $\mathrm{La} / \mathrm{Sm}$ ratios with increasing $\mathrm{SiO}_{2}$ (Figs 12c-d), which indicate that Elbeyli and Emeksen magmas come from nearly the same depth. However, higher $\mathrm{La} / \mathrm{Sm}$ ratios, more distinct decreasing $\mathrm{La} / \mathrm{Sm}$ ratios with increasing $\mathrm{Sm} / \mathrm{Yb}$ ratios, and increasing $\mathrm{La} / \mathrm{Sm}$ ratios with increasing $\mathrm{SiO}_{2}$ contents in the Emeksen samples can be explained by crustal contamination. Partial melting of the lower continental crust can result in LREE enrichments (e.g. Lassiter and DePaolo, 1997), therefore the later trends of the granodiorite to granite at Emeksen (Figs 12cd) reveal that the related magmas were transferred more rapidly to upper crustal levels and interacted more intensively with upper crustal materials.

Average $\mathrm{Zr} / \mathrm{Y}, \mathrm{Nb} / \mathrm{Y}$ and $\mathrm{Ce} / \mathrm{Y}$ ratios of the Elbeyli (7, 0.5 and 2.6, respectively) and the Emeksen (6, 0.5 and 2.7, respectively) samples are roughly similar to those of the upper crust $(\mathrm{Zr} / \mathrm{Y}=9 ; \mathrm{Nb} / \mathrm{Y}=0.6 ; \mathrm{Ce} / \mathrm{Y}=3$, Rudnick and Gao 2003). The Emeksen and Elbeyli samples plot mostly in the partial amphibolite melt field, and the $\mathrm{Nb} / \mathrm{Ta}$ vs. $\mathrm{Zr} / \mathrm{Sm}$ plot indicates that the Elbeyli and Emeksen samples are consistent with magmas produced by amphibolite/hornblende eclogite melting (Fig 13).

Based on these data, we can conclude that the high-K calc-alkaline Emeksen and shoshonitic Elbeyli magmas were derived from a metasomatised and heterogeneous lithospheric mantle source within the mantle wedge overlying the subducted plate. However, the Elbeyli monzonitic magma interacted more intensively and/or for a longer time with an enriched lithospheric mantle than the Emeksen magmas. Magma 
influx from the metasomatised lithospheric mantle into lower-middle crust most probably resulted in crustal partial melting of amphibolitic mid-low crustal materials. However, while the Elbeyli magma was evolving at mid-crustal levels $(\sim 10-20 \mathrm{~km})$ involving low-pressure clinopyroxene-amphibole-plagioclase fractionation, the Emeksen magma evolved at upper crustal levels $(\sim 0-10 \mathrm{~km})$, including differentiation through fractional crystallization and crustal contamination/assimilation. In addition, it is possible that more primitive magmas from the lithospheric mantle and/or the lower crust may have reached upper crustal levels, possibly during stress relaxation of the crust as a result of slab roll-back during northward subduction. This is likely the case of the magmas at the origin of the Elbeyli shoshonitic rocks, and some of them may have mixed or mingled with high-K calc-alkaline to calc-alkaline magmas emplaced at upper crustal levels.

\subsection{Geodynamic setting and mineralizations}

The Upper Cretaceous ages of the host rocks of the Elbeyli $(77.0 \pm 1.3 \mathrm{Ma})$, Emeksen $(77.7 \pm 0.5 \mathrm{Ma}, 78.5 \pm 0.8 \mathrm{Ma}$, and $78.7 \pm 0.5 \mathrm{Ma})$ and Güzelyayla prospects $(81.4 \pm 1.1$ Ma) agree well with the age of other subduction-related granitoids of the Eastern Pontides (Fig 2). Therefore, our new geochronological and geochemical data indicate that the Elbeyli, Emeksen and Güzelyayla intrusions are the product of arc magmas linked to northward subduction of the Neotethys beneath the Eurasian plate.

One of the on-going debates about the geodynamic evolution of the Eastern Pontides is the onset age of subduction, as the ages proposed range from the Late Cretaceous (e.g. Okay and Şahintürk, 1997, Okay, 2008) to Jurassic or earlier (e.g. Adamia et al., 1977, 1981; Kazmin et al., 1986). According to Okay and Şahintürk 
(1997), the volcanic arc developed during the Turonian to Maastrichtian-Danian (Fig 2). However, the Early Cretaceous ages $(131.1 \pm 0.9 \mathrm{Ma}$ and $132.9 \pm 0.6 \mathrm{Ma})$ of the calc-alkaline magmatic rocks from the Ispir-Ulutaş prospect and the presence of Early Cretaceous calc-alkaline granitoids in the eastern part of the Eastern Pontides (e.g. 142 Ma-old Rize pluton, Taner, 1977; 138.5£2.2 Ma-old Çamlıkaya granitoid, Boztuğ and Harlavan, 2008; 132 \pm 5 Ma-old Ispir batholith, Giles, 1973) indicate that subduction was already on-going during the Early Cretaceous. In addition, geochronological data from the metamorphosed oceanic accretionary and/or ophiolite complexes in the Eastern Pontides and the Lesser Caucasus support northward subduction of the northern branch of the Neotethys (Izmir-AnkaraErzincan-Sevan-Akera oceanic basin) from the Late Paleozoic to the Late Mesozoic - Early Cenozoic (e.g. Boztuğ and Harlavan, 2008; Galoyan et al., 2009; Hässig et al., 2013; Nikishin et al., 2011; Rolland et al., 2010, 2011; Topuz et al., 2013b, 2014; Ustaömer et al., 2012). Therefore, the Lower Cretaceous ore-bearing granitoids in the Eastern Pontides agree well with the long-lasting subduction model proposed for the Eastern Pontides and the adjacent Lesser Caucasus from Late Paleozoic to the end of the Mesozoic (e.g. Adamia et al., 1981; Galoyan et al., 2009; Hässig et al., 2013; Rolland et al., 2010, 2011; Topuz et al., 2013b; Ustaömer et al., 2012). Furthermore, gradual lateral changes of the age and the nature of magmatism from Lower Cretaceous calc-alkaline in the east to Upper Cretaceous high-K calc-alkaline in the central part of the belt, and to Upper Cretaceous mantle-dominated shoshonitic composition in the west (Figs $\mathbf{1}$ and $\mathbf{3 d}$ ), together with the absence of the Lower Cretaceous granitoids in the west of the belt, indicate that subduction may have started earlier in the eastern part of the belt. 
Geochronological data by Karslı et al. (2012a) and Kaygusuz et al. (2014) and our data indicate that the high-K, calc-alkaline, shoshonitic to A-type granitoids were emplaced within a ca. 81 to 74 Ma time interval in the Eastern Pontides. Karslı et al. (2010, 2012a) concluded that the A-type and shoshonitic granitic magmas were emplaced in an extensional environment during subduction, reflecting transition from a compressional to an extensional arc setting attributed to slab roll-back, which started at ca. 79-81 Ma in the Eastern Pontides. VMS deposits in the Eastern Pontides hosted by Turonian $(91.1 \pm 1.3 \mathrm{Ma})$ and Upper Santonian to Lower Campanian $(86.6 \pm 0.8 \mathrm{Ma}$ to $82.6 \pm 1.0 \mathrm{Ma})$ felsic rocks are also attributed to an extensional environment (Eyüboğlu et al., 2014). The Turonian ages of the VMS host rocks are consistent with the age of high- $\mathrm{K}$ calc-alkaline to shoshonitic rocks from the Eastern Pontides, supporting the existence of a back-arc environment at the beginning of the Late Cretaceous along the belt. This agrees with Nikishin et al. (2011), who suggest back-arc basin opening during the Cenomanian to Coniacian. Therefore, our new geochronological and geochemical data allow us to conclude that the emplacement of magmatic rocks and mineralization at the Ispir-Ulutaş prospect may have been related to the main stage of the Early Cretaceous northward subduction of the Neotethys. While the Güzelyayla and Emeksen hydrothermal systems can be attributed to a transitional evolution from compression to extension, Upper Cretaceous shoshonitic magmatism, sourced by an enriched lithospheric mantle, and the associated hydrothermal system at Elbeyli could be the products of arc magmatism during an extensional stage, as a result of slab roll-back, rather than to the onset of subduction. This Late Cretaceous setting may also be responsible for the opening of the Black Sea basin in the north during the final stage of subduction, 
before the accretion of the Anatolide-Tauride-South Armenian block (Karslı et al., 2010, 2012a; Rolland et al., 2012; Stephenson and Schellart, 2010).

Extensional tectonic settings and crustal thinning are generally thought to be unsuitable environments for the formation of giant porphyry deposits (e.g. Cook et al., 2005; Sillitoe, 2010). However extensional tectonics during subduction is interpreted to be a favourable environment for migration into upper crustal levels of highly oxidized, mantle-derived magmas, which are commonly linked to the formation of copper-gold mineralization (e.g. Candela and Bouton, 1990; Vigneresse, 2007). Therefore, we used the V/Sc ratio of the rocks investigated in this study to evaluate the oxidation states of magmas from the Elbeyli and Emeksen prospects (Kamvong et al., 2014; Lee et al., 2005) (Fig 14). The MgO versus V/Sc diagram, modified after Lee et al. (2005), was originally used to estimate the primary $\mathrm{fO}_{2}$ during mantle melting for adakites in the Truong Son and Loei fold belts of Thailand and Laos (Kamvong, et al., 2014). In this study, we use it to estimate the oxidization states of ore-bearing high-K calc-alkaline to shoshonitic rocks of the Elbeyli and Emeksen prospects. According to the MgO vs. V/Sc plot (Fig 14), the Elbeyli samples cluster at model $\Delta \operatorname{logfO}_{2}$ values between the $\mathrm{FMQ}$ (fayalite-magnetite-quartz buffer) around +1 and $>+3$. The Emeksen granitic samples cluster between the $F M Q$ and a $F M Q+3$, and gabbroic samples of the Emeksen prospect lie around a FMQ -1. By contrast, the $\mathrm{V} / \mathrm{Sc}$ values of the non-mineralized Eocene adakitic intrusions of the Eastern Pontides (Karslı et al., 2011) vary between a FMQ -1 to a FMQ+1. This indicates that the Elbeyli and Emeksen magmatic rocks were derived from more oxidized magmas than the barren Eocene adakitic intrusions of the Eastern Pontides. In addition, the Elbeyli samples correspond to more oxidizing conditions in comparison to the 
Emeksen samples, which is also expressed by the high-sulfidation mineral association, including enargite with euhedral pyrite, at the Elbeyli prospect.

Molybdenum-bearing environments, such as at the Elbeyli and Emeksen prospects, are generally associated with less oxidized magmas (e.g. Bao et al., 2014; Candela and Bouton, 1990; Oyarzun et al., 2001, 2002), because molybdenum has an incompatible behavior under high oxidizing conditions (Candela, 1992). Therefore, the widespread occurrence of molybdenum, rather than copper and gold enrichments in the Emeksen and Elbeyli prospects cannot be explained only by highly oxidized magmas. Enargite and euhedral pyrite replaced by tennantite and tetrahedrite along rims and fractures at the Elbeyli prospect reveal decreasing sulfur and oxygen fugacities during hydrothermal fluid evolution, which is a favorable environment for molybdenum precipitation, as evidenced by its occurrence along fractures/cracks within euhedral pyrite and enargite. Accordingly, the high-sulfidation mineralization and the associated advanced argillic alteration with zunyite and pyrophyllite, reflect the uppermost level of the hydrothermal system, which developed under these highly oxidizing conditions. Decreasing oxygen fugacity may explain molybdenum precipitation as well as tennantite and tetrahedrite replacements. We conclude that the shoshonitic mantle-derived magma at Elbeyli is the most likely source of the hydrothermal fluids and metals.

Although there is no consensus about the crustal versus mantle origin of molybdenum in porphyry deposits (Richards, 2011), magma mixing and crustal contamination at the Emeksen, Güzelyayla and Ispir-Ulutaş prospects may have played an important role during molybdenum enrichment and hydrothermal evolution 
at these prospects. Continuous mafic magma influx from the mid to lower crust most probably supplied heat and volatiles and may have remobilized molybdenum in the upper crustal levels.

\section{Conclusions}

The host rocks of the Elbeyli, Emeksen, Güzelyayla and Ispir-Ulutaş prospects share many affinities with other I-type subduction-related Upper Cretaceous granitoids in the Eastern Pontides. New U-Pb ages of zircon grains from the intrusive host rocks show that porphyry-type mineralizations were formed between about 133 to $76 \mathrm{Ma}$ (Fig 2). Three independent porphyry mineralization events were identified from east to west: (i) at ca. 133-130 Ma at the Ispir-Ulutaş prospect, (ii) ca. 82-77 Ma at the Güzelyayla and Emeksen prospects, and (iii) ca. 77-76 Ma at the Elbeyli prospect. Recognition of these three porphyry events allowed us to constrain the geodynamic evolution of the Eastern Pontides during the Cretaceous, starting with (i) 133-130 Ma-old calc-alkaline magmatic host rocks of the Ispir-Ulutaş prospect emplaced during the main Early Cretaceous subduction stage of the northern branch of the Neotethys Ocean, (ii) calc-alkaline, high-K calc-alkaline to shoshonitic magmatic host rocks of the Güzelyayla and Emeksen prospects attributed to a transitional compressional to extensional setting at ca. $100-77 \mathrm{Ma}$, and (iii) magmatic host rocks of the Elbeyli prospect attributed to an extensional tectonic stage at ca. 77-66 Ma. (Fig 2). Based on the east to west compositional and age trend of the magmatic host rocks and the abundant Lower Cretaceous calc-alkaline granitoids in the eastern part of the belt, we conclude that subduction started in the east and progressively progressed to the west. Extensional tectonics was contemporaneous with subduction and shaped the entire belt during the Late Cretaceous. Therefore, Early Cretaceous 
subduction-related calc-alkaline magmatism is a good fertility indicator for evolved porphyry Cu-Mo systems in the eastern part of the belt. On the other hand, although extensional and transitional tectonic settings during subduction are considered as unsuitable environments for the formation of giant porphyry deposits, highly-oxidized mantle derived shoshonitic magmas, modified during crustal contamination and magma mixing/mingling processes, could have played an important role in the formation of small Cu-Mo $\pm A u$-bearing porphyry-type systems, especially in the western part of the Eastern Pontides.

\section{Acknowledgments}

The authors thank Hervé Rezeau and Bjoern Baresel (University of Geneva) for help during Electron Microprobe analyses, Fabio Capponi for XRF analyses (University of Geneva) and Dr. Oktay Parlak and Mustafa Özkan (MTA) during field studies. We are also grateful to Demir Export Company (Dr. Özcan Dumanlılar) for their support. Dr. Yann Rolland, Dr. Ghazar Galoyan and Dr. Sun-Lin Chung (editor) are thanked for their valuable comments and suggestions that allowed us to improve the manuscript. The research was supported by the Swiss National Science Foundation through the

research grant 200020-155928 and supported by the E. Pontides Metallic Mineral Exploration Project-2014-32-13-08 of the General Directorate of Mineral Research and Exploration, Turkey (MTA). Okan Delibaş was supported by a post-doctoral TUBITAK Scholarship (2219-International Post-Doctoral Research Fellowship Programme) at the University of Geneva during 2013-2014. 


\section{References}

Abratis, M., 1998. Geochemical variations in magmatic rocks from southern Costa

Rica as a consequence of Cocos Ridge subduction and uplift of the Cordillera de Talamanca. Ph.D. thesis, Göttingen University, 136p.

Adamia, S.A., Lordkipanidze, M.B., Zakariadze, G.S., 1977. Evolution of an active continental margin as exemplified by the Alpine history of the Caucasus. Tectonophysics 40, 183-199.

Adamia, S.A., Chkhotua, T., Kekelia, M., Lordkipanidze, M., Shavishvili, I. Zakariadze, G., 1981. Tectonics of the Caucasus and adjoining regions: implications for the evolution of the Tethys ocean. Journal of Structural Geology 3, 437-447.

Akın, H., 1978. Geologie Magmatismus und Lagerstaettenbildung im ost pontischen Gebirge-Türkei aus der Sicht der Plattentektonik. Geological Rundschau 68, 253283.

Akıncı, O.T., 1980. Major copper metallogenic units and genetic igneous complexes of Turkey, in: Jankovic, S., Sillitoe, R.H. (Eds.), European Copper Deposits. Belgrade University Faculty Geology Mining, Belgrade, pp. 208-219.

Akıncı, O.T., 1984. The Eastern Pontide volcano-sedimentary belt and associated massive sulphide deposits. Geological Society of London, Special Publications 17, 415-428.

Altherr, R., Topuz, G., Siebel, W., Şen, C., Meyer, H., Satir, M., Lahaye, Y., 2008. Geochemical and $\mathrm{Sr}-\mathrm{Nd}-\mathrm{Pb}$ isotopic characteristics of Paleocene plagioleucitites from the Eastern Pontides (NE Turkey). Lithos 105, 149-161. 
Arslan, M., Aslan, Z., 2006. Mineralogy, petrography and whole-rock geochemistry of the Tertiary granitic intrusions in the Eastern Pontides, Turkey 27, 177-193.

Bao, Z.W., Wang, Y. Zhao, T.P., Li, C.F., Gao, X.Y., 2014. Petrogenesis of the Mesozoic granites and Mo mineralization of the Luanchuan ore field in the East Qinling Mo mineralization belt, Central China, Ore Geology Reviews 57, 132-153.

Beccaluva, L., Bianchini, G., Bonadiman, C., Siena, F., Vaccaro, C., 2004. Coexisting anorogenic and subduction-related metasomatism in mantle xenoliths from the Betic Cordillera (southern Spain). Lithos 75, 67-87.

Boekhout, F., Spikings, R., Sempere, T., Chiaradia, M., Ulianov, A., Schaltegger, U., 2012. Mesozoic arc magmatism along the southern Peruvian margin during Gondwana breakup and dispersal. Lithos 146-147, 48-64.

Boynton, W.V., 1984. Cosmochemistry of the rare earth elements: in: Henderson, P. (Ed.), Meteorite studies, Rare element geochemistry, Amsterdam, Elsevier, pp.63114.

Boztuğ, D., Harlavan, Y., 2008. K-Ar ages of granitoids unravel the stages of NeoTethyan convergence in the eastern Pontides and central Anatolia, Turkey. Int. J. Earth Sci. 97, 585-599. doi:10.1007/s00531-007-0176-0

Boztuğ, D., Jonckheere, R.C., Wagner, G.A., Yeğingil, Z., 2004. Slow Senonian and fast Paleocene-Early Eocene uplift of the granitoids in the Central eastern Pontides, Turkey: apatite fission-track results. Tectonophysics 382, 213-228. 
Candela, P.A., 1992. Controls on ore metal ratios in granite related ore systems: An experimental and computational approach: Royal Society of Edinburgh Transactions, Earth Sciences 83, 317-326.

Candela, P. A., Bouton, S. L., 1990. The influence of oxygen fugacity on tungsten and molybdenum partitioning between silicate melts and ilmenite. Economic Geology $85,633-640$.

Castillo, P.R., Janney, P.E., Solidum, R.U., 1999. Petrology and geochemistry of Camiguin Island, southern Philippines: insights to the source of adakites and other lavas in a complex arc setting. Contributions to Mineralogy and Petrology 134, 3351.

Chiaradia, M., Merino, D., Spikings, R., 2009a., Rapid transition to long-lived deep crustal magmatic maturation and the formation of giant porphyry-related mineralization (Yanacocha, Peru). Earth and Planetary Science Letters 288, 505515.

Chiaradia, M., Müntener, O., Beate, B., Fontignie, D., 2009b. Adakite-like volcanism of Ecuador: lower crust magmatic evolution and recycling. Contributions to mineralogy and Petrology 158, 563-588.

Chiaradia, M., Müntener, O., Beate, B., 2011. Enriched basaltic andesites from midcrustal fractional crystallization, recharge, and assimilation (Pilavo Volcano, Western Cordillera of Ecuador). Journal of Petrology 52, 1107-1141.

Conticelli, S., D'Antonio, M., Pinarelli, L., Civetta, L., 2002. Source contamination and mantle heterogeneity in the genesis of Italian potassic and ultrapotassic volcanic 
rocks: $\mathrm{Sr}-\mathrm{Nd}-\mathrm{Pb}$ isotope data from Roman Province and Southern Tuscany. Mineralogy and Petrology 74, 189-222.

Cooke, D.R., Hollings, P., Walshe, J.L., 2005. Giant porphyry deposits: Characteristics, distribution, and tectonic controls. Economic Geology 100, 801-818.

Çağatay, M.N., Boyle, D.R., 1977. Geochemical prospecting for volcanogenic sulfide deposits in the eastern black sea ore province, Turkey. Journal of Geochemical Exploration 8, 1-2, 49-71.

Çınar, S., Yazıcı, E.N., 1985. Trabzon-Maçka-Güzelyayla köyü bakır-molibden zuhuru ve civarına ait rapor. General Directorate of Mineral Research and Exploration Report (MTA), Report No: 8025, (in Turkish, unpublished).

Davidson, J., Turner, S., Handley,H., Macpherson, C., Dosseto, A., 2007. Amphibole "sponge" in arc crust? Geology 35, 787-790.

Defant, M.J., Drummond, M.S., 1990. Derivation of some modern arc magmas by melting of young subducted lithosphere. Nature 347, 662-665.

Delibaş, O., Moritz, R., Ulianov, A., Chiaradia, M., Göç, D., Revan, M.K., 2014. Timing and Geochemical Characteristics of Magmatism Associated with PorphyryType Mineralization in the Eastern Pontides, Turkey: Implications for ore-formation within the Pontide Paleo-Magmatic Arc. XX Congress of the Carpathian Balkan Geological Assocaition, Tirana, vol. 1, pp. 151-152.

Delibaş, O., Moritz, R., Baresel, B., Genç, Y., Göç, D., 2015a. Zunyite-bearing alteration assemblage and its genetic importance: The first report from a $\mathrm{Cu}-\mathrm{Mo}-\mathrm{Au}$ 
mineralization in the Eastern Pontides at Elbeyli, Turkey. Proceedings of the $12^{\text {th }}$ International Congress for Applied Mineralogy, Istanbul, pp.20.

Delibaş, O., Moritz, R., Ulianov, A., Chiaradia, M., Göç, D., Özkan, M., Revan., M.K., 2015b. Genesis of the Late Cretaceous Emeksen (Giresun) porphyry $\mathrm{Mo} \pm \mathrm{Cu}$ mineralization, Eastern Pontides, Turkey. Proceedings of the 68th Geological Congress of Turkey, pp. 368-369.

DePaolo, D.J., 1981. Trace-element and isotopic effects of combined wallrock assimilation and fractional crystallization. Earth and Planetary Science Letters 53(2): 189-202.

Dogan, R., 1980. The granitic rocks and related molybdenite mineralization of the Emeksan area, Espiye, N.E.Turkey. Ph.D. thesis, Durham University.

Doglioni, C., Harabaglia, P., Merlini, S., Mongelli, F., Peccerillo, A., Piromallo, C., 1999. Orogens and slabs vs. their direction of subduction. Earth-Science Reviews 45, 167-208.

Dokuz, A., Tanyolu, E., Genç, S., 2006. A mantle- and a lower crust-derived bimodal suite in the Yusufeli (Artvin) area, NE Turkey: trace element and REE evidence forsubduction-related rift origin of Early Jurassic Demirkent intrusive complex. International Journal of Earth Sciences 95, 370-394.

Dokuz, A., Karsli, O., Chen, B., Uysal, I., 2010. Sources and petrogenesis of Jurassic granitoids in the Yusufeli area, Northeastern Turkey: implications for pre- and postcollisional lithospheric thinning of the Eastern Pontides. Tectonophysics 480, 259-279. 
Eğin, D., Hirst, D. M., Phillips, R., 1979. The petrology and geochemistry of volcanic rocks from the northern Harşit River area, Pontide volcanic province, northeast Turkey. Journal of Volcanology and Geothermal Research 6, 105-123

Er, M., Özdoğan, K., Tüysüz, N., 1992. Geology and mineralization of Güzelyayla Porphyry Cu-Mo occurrence, Trabzon, NE Turkey. Pre. International Symposium on the Geology of the Black Sea region 226-231.

Ernst, E.R., Buchan, K.L., 2003. Recognizing mantle plumes in the geological record. Annual Review of Earth Planetary Sciences 31, 469-523.

Eyüboğlu, Y., 2010. Late Cretaceous high-K volcanism in the eastern Pontide orogenic belt: implications for the geodynamic evolution of NE Turkey. International Geology Review 52 (2-3), 142-186.

Eyüboğlu, Y., Santosh, M., Yi, K., Tuysuz, N., Korkmaz, S., Akaryali, E., Dudas, F.O., Bektas, O., 2014. The Eastern Black Sea-type volcanogenic massive sulfide deposits: Geochemistry, zircon $\mathrm{U}-\mathrm{Pb}$ geochronology and an overview of the geodynamics of ore genesis. Ore Geology Reviews 59, 29-54.

Foley, S.F., 1992. Veins plus wall-rock melting mechanism in the lithosphere and the origin of potassic alkaline magmas. Lithos $28,435-453$.

Furman, T., Graham, D., 1999. Erosion of lithospheric mantle beneath the East African Rift system: geochemical evidence from the Kivu volcanic province. Lithos $48,237-262$.

Galoyan, G., Rolland, Y., Sosson, M., Corsini, M., Billo, S., Verati, C., Melkonyan, R., 2009. Geology, geochemistry and ${ }^{40} \mathrm{Ar} /{ }^{39} \mathrm{Ar}$ dating of Sevan ophiolites (Lesser 
Caucasus, Armenia): evidence for Jurassic Back-arc opening and hot spot event between the South Armenian Block and Eurasia. Journal of Asian Earth Sciences 34, 135-153.

Gedik, A., Ercan, T., Korkmaz, S., Karataş, S., 1992, Petrology of the magmatic rocks in the area between Rize. Fındıklı and Çamlıhemşin (eastern Black sea region) and their distribution in the Eastern Pontides. Türkiye Jeoloji Bülteni 35, 15-38 (in Turkish with English abstract).

Gedikoğlu, A., 1978. Harşit granite complex and neighboring rocks (Giresun Doğankent). Ph.D. thesis, Black Sea Technical University, Trabzon, Turkey, 161p.

Giles, D.L., 1973. Geology and mineralization of the Ulutaş copper-molybdenum deposits, Eastern Anatolia, Turkey. United Nations Development Programme, Technical Report 6, 56.

Görür, N., 1988. Timing of opening of the Black Sea basin. Tectonophysics 147, 247262.

Güner, S., Güç, A.R., 1990. Trabzon-Maçka-Güzelyayla yöresindeki porfiri tip Cu-Mo maden jeolojisi raporu. General Directorate of Mineral Research and Exploration Report (MTA), Report No: 41770, (in Turkish, unpublished).

Hässig, M., Rolland, Y., Sosson, M., Galoyan, G., Sahakyan, L., Topuz, G., Çelik, Ö.F., Avagyan, A., Müller, C., 2013. Linking the NE Anatolian and Lesser Caucasus ophiolites: evidence for large scale obduction of oceanic crust and implications for the formation of the Lesser Caucasus-Pontides Arc. Geodinamica Acta 26 (3-4), 311 350. 
Hora, J. M., Singer, B. S., Worner, G., Beard, B. L., Jicha, B. R., Johnson, C. L., 2009. Shallow and deep control on differentiation of calc-alkaline and tholeiitic magma. Earth and Planetary Science Letters 285, 75-86.

Irvine, T. N., Baragar, W.R.A., 1971. A guide to the chemical classification of common volcanic rocks. Canadian Journal of Earth Sciences 8, 523- 548.

Jackson, S.E., 2008. Lamtrace data reduction software for LA-ICP-MS, in: Sylvester, P. (Ed.), Laser Ablation ICP-MS in the Earth Sciences: Current Practices and Outstanding Issues. Mineralogical Association of Canada Short Course Series 40, 305-307.

Kamitani, M., Takaoğlu, S., Bektaş, O., Kahaman, I., 1977. Molybdenum deposits of Çakıldağ Area, Espiye, NE Turkey. General Directorate of Mineral Research and Exploration Report (MTA), Report No: 6313, 38p. (unpublished).

Kamvong, T., Zaw, K., Meffre, S., Maas, R., Stein, H., Lai, C-K., 2014. Adakites in the Truong Son and Loei fold belts, Thailand and Laos: Genesis and implications for geodynamics and metallogeny. Gondwana Research 26(1), 165-184.

Karsı, O., Dokuz, A., Uysal, İ., Aydın, F., Chen, B., Kandemir, R., Wijbrans, J., 2010. Relative contributions of crust and mantle to generation of Campanian high-K calcalkaline I-type granitoids in a subduction setting, with special reference to the Harşit Pluton, Eastern Turkey. Contributions to Mineralogy and Petrology 160, 467-487.

Karsli, O., Uysal, I., Ketenci, M., Dokuz, A., Aydin, F., Kandemir, R., Wijbrans, J., 2011. Adakite-like granitoid porphyries in Eastern Pontides, NE Turkey: potential parental melts and geodynamic implications. Lithos 127, 354-372. 
Karslı, O., Caran, Ş., Dokuz, A., Çoban, H., Chen, B., Kandemir, R., 2012a. A-type granitoids from the Eastern Pontides, NE Turkey: records for generation of hybrid Atype rocks in a subduction-related environment. Tectonophysics 530-531, 208-224.

Karslı, O., Dokuz, A., Uysal, İ., Ketenci, M., Chen, B., Kandemir, R., 2012b. Deciphering the shoshonitic monzonites with I-type characteristic, the Sisdagi pluton, NE Turkey: magmatic response to continental lithospheric thinning. Journal of Asian Earth Sciences 51, 45-62.

Kay, R.W., Kay, S.M., 1991. Creation and destruction of lower continental crust: Geological Rundschau 80, 259-278.

Kaygusuz, A., Şen, C., 2011. Calc-alkaline I-type plutons in the eastern Pontides, NE Turkey: $\mathrm{U}-\mathrm{Pb}$ zircon ages, geochemical and $\mathrm{Sr}-\mathrm{Nd}$ isotopic compositions. Chemie der Erde-Geochemistry 71, 59-75.

Kaygusuz, A., Wolfgang, S., Şen., C., Satır, S., 2008. Petrochemistry and petrology of Itype granitoids in an arc setting: the composite Torul pluton, eastern Pontides, NE Turkey. International Journal of Earth Sciences 97, 739-764.

Kaygusuz, A., Chen, B., Aslan, Z., Wolfgang, S., Şen, C., 2009. U-Pb zircon SHRIMP ages, geochemical and $\mathrm{Sr}-\mathrm{Nd}$ isotopic compositions of the Early Cretaceous I type Sarıosman pluton, eastern Pontides, NE Turkey. Turkish Journal of Earth Sciences 18, 549-581.

Kaygusuz, A., Sipahi, F., İlbeyli, N., Arslan,M., Chen, B., Aydınçakır, E., 2013. Petrogenesis of the Late Cretaceous Turnagöl intrusion in the eastern Pontides: implications for magma genesis in the arc setting. Geoscience Frontiers 4, 423-438. 
Kaygusuz, A., Arslan, M., Siebel, W., Sipahi, F., İlbeyli, N., Temizel, İ., 2014. LA-ICPMS zircon dating, whole-rock and $\mathrm{Sr}-\mathrm{Nd}-\mathrm{Pb}-\mathrm{O}$ isotope geochemistry of the Camiboğazı pluton, Eastern Pontides, NE Turkey: Implications for lithospheric mantle and lower crustal sources in arc-related, I-type magmatism. Lithos 192-195, 271-290.

Kazmin, V., Sbortshikov, I., Ricou, L.E., Zonenshain, L., Boulin, J., Knipper, A., 1986. Volcanic belts as markers of the Mesozoic-Cenozoic active margin of Eurasia. Tectonophysics 123, 123-152.

Ketin, I., 1966, Tectonic units of Anatolia. MTA Bulletin 66, 23-34.

Lassiter,C.J., DePaolo, J.D., 1997. Plume/Lithosphere interaction in the generation of continental and oceanic flood basalts: Chemical and isotopic constrains, in: Mahoney, J.J and Coffin, F.M. (Eds.), Large igneous provinces, continental, oceanic, and Planetary flood volcanism. American Geophysical Union, Washington, Geophysical Monograph 100, 522.

Lee, C.T., Leeman, W.P., Canil, D., Li, Z.X., 2005. Similar V/Sc systematics in MORB and arc basalts: implications for the oxygen fugacities of their mantle source regions. Journal of Petrology 46, 2313-2336.

Ludwig, K.R., 2012. User's Manual for Isoplot 3.75, A Geochronological Toolkit for Microsoft Excel. Berkeley Geochronology Center Special Publication No. 5.

Manetti, P., Peccerillo, A., Poli, G., Corsini, F., 1983. Petrochemical constrains on the models of Cretaceous-Eocene tectonic evolution of the eastern Pontic Chain (Turkey). Cretaceous Research 4, 159-172. 
Macpherson, C.G., Dreher, S.T., Thirlwall, M.F., 2006. Adakites without slab melting: high pressure differentiation of island arc magma, Mindanao, the Philippines. Earth and Planetary Science Letters 243, 581-593.

Meen, J.K., Eggler, D.H., 1987. Petrology and geochemistry of the Cretaceous Independence Volcanic Suite, Absaroka Mountains, Montana: clues to the composition of the Archean sub-Montanan mantle. Geological Society of American Bulletin 98, 238-247.

Middlemost, E.A.M., 1985. Magmas and magmatic rocks: An introduction to igneous peterology. Longman. Inc., New York.

MTA., 1984. Türkiye molibden envanteri, Maden Tetkik Arama Genel Müdürlüğü Yayınları, No:191, Ankara (in Turkish).

MTA., 2002. 1/500.000 ölçekli Türkiye jeoloji haritası Trabzon paftası, in: Akdeniz, N., Güven, İ. (Eds.), General Directorate of Mineral Research and Exploration (MTA) Publication (in Turkish).

Muller D., Groves, D.I., 1995. Potassic igneous rocks and associated gold-copper mineralization: Lecture Notes in Earth Sciences 56, Springer-Verlag, Heidelberg.

Nikishin, A.M., Ziegler, P.A., Bolotov, N.S., Fokin, P.A., 2011. Late Palaeozoic to Cenozoic Evolution of the Black Sea-Southern Eastern Europe Region: A View from the Russian Platform. Turkish Journal of Earth Sciences 21, 571-634.

Nebioğlu, T.Y., 1983. Trabzon-Maçka-Güxelyayla köyü civarındaki porfiri tip Cu-Mo zuhurlarına ait ön rapor. General Directorate of Mineral Research and Exploration Report (MTA), Report No: 7817, (in Turkish, unpublished). 
Okay, A., 2008. Geology of Turkey: A synopsis. Anschnitt 21, 19-42.

Okay, A., Şahintürk, Ö., 1997. Geology of Pontides, in: Robinson, A. (Ed.), Regional and Petroleum Geology of Black Sea and Surrounding Regions. American Association of Petroleum Geologists, Memoir 68, pp. 291-311.

Okay, A., Tüysüz, O., 1999. Tethyan sutures of northern Turkey, in: Durand, B., Jolivert, L., Horvath, F., Seranne, M. (Eds.), The Mediterranean Basin: Tertiary Extension within the Alpine Orogen. Geological Society of London, London, pp. 475515.

Oyarzun, R., Márquez, A., Lillo, J., López, I., Rivera, S., 2001. Giant versus small porphyry copper deposits of Cenozoic age in northern Chile: adakitic versus normal calcalkaline magmatism. Mineralium Deposita 36, 794-798.

Oyarzun, R., Márquez, A., Lillo, J., López, I., Rivera, S., 2002. Reply to discussion on "Giant versus small porphyry copper deposits of Cenozoic age in northern Chile: adakitic versus normal calc-alkaline magmatism" by Oyarzun et al. (Mineralium Deposita 36: 794-798, 2001). Mineralium Deposita 37, 791-794.

Pearce J. A., 1983. Role of the sub-continental lithosphere in magma genesis at active continental margins, in: Hawkesworth, C.J., Norry, M.J. (eds.). Continental basalts and mantle xenoliths. Shiva Publishing Ltd., Cambridge, pp. 230-272.

Peccerillo, A., Taylor, S.R., 1975. Geochemistry of Upper Cretaceous volcanic rocks from the Pontic chain, Northern Turkey. Bulletin of Volcanology 39/4, 557-569.

Pejatoviç, S., 1979. Metallogeny of the Pontid-type massive sulfide deposits. General Directorate of Mineral Research and Exploration Publication 177, 98p. 
Revan, M.K., 2010. Determination of the typical properties of volcanogenic massive sulfide deposits in the eastern black sea region. Ph.D. thesis, (in Turkish), Hacettepe University, $320 \mathrm{p}$.

Revan, M.K., Genç, Y., Maslennikov, V., Taner, Ü., Delibaş, O., Hamzaçebi, S., 2014. Original Findings on the Ore-Bearing Facies of Volcanogenic Massive Sulphide Deposits in the Eastern Black Sea Region (NE Turkey). Bulletin of the Mineral Research and Exploration 147, 73-89.

Richards, J.P., 2011. Magmatic to hydrothermal metal fluxes in convergent and collided margins. Ore Geology Reviews 40, 1-26.

Richards, J.P., Spell, T., Rameh, E., Razique, A., Fletcher, T., 2012. High Sr/Y magmas reflect arc maturity, high magmatic water content, and porphyry $\mathrm{Cu} \pm \mathrm{Mo} \pm$ Au potential: Example from the Tethyan arcs of central and eastern Iran and western Pakistan. Economic Geology 107, 295-332.

Roberts, M.P., Clemens, J.D., 1993. Origin of high-potassium, calc-alkaline, I-type granitoids. Geology 21, 825-828.

Rodriguez, C., Selles, D., Dungan, M., Langmuir, C., Leeman, W., 2007. Adakitic dacites formed by intracrustal crystal fractionation of water-rich parent magmas at Nevado de Longavi Volcano $\left(36.2^{\circ} \mathrm{S}\right.$; Andean Southern Volcanic Zone, Central Chile). Journal of Petrology 48, 2033-2061.

Rolland, Y., Billo, S., Corsini, M., Sosson, M., Galoyan, G., 2009a. Blueschists of the Amassia-Stepanavan Suture Zone (Armenia): linking Tethys subduction history from E-Turkey to W-Iran. International Journal of Earth Sciences 98, 3, 533-550. 
Rolland, Y., Galoyan, G., Bosch, D., Sosson, M., Corsini, M., Fornari, M., Vérati, C., 2009b. Jurassic Back-arc and hot-spot related series in the Armenian ophiolites Implications for the obduction process. Lithos 112, 163-187.

Rolland, Y., Galoyan, G., Sosson, M., Melkonian, R., Avagyan, A., 2010. The Armenian ophiolites: insights for Jurassic back-arc formation, Lower Cretaceous hotspot magmatism, and Upper Cretaceous obduction over the South Armenian Block, in: Sosson, M., Kaymakci, N., Stephenson, R. A., Bergerat, F., Starostenko, V. (Eds), Sedimentary Basin Tectonics from the Black Sea and Caucasus to the Arabian Platform Sedimentary. Geological Society, London, Special Publication 340, pp. 353382.

Rolland, Y., Sosson, M., Adamia, S., Sadradze N., 2011. Prolonged 'Variscan to Alpine' history of Active Eurasian margin (Georgia, Armenia) revealed by $40 \mathrm{Ar} / 39 \mathrm{Ar}$ dating. Gondwana Research 20, 798-815.

Rolland, Y., Perincek, D., Kaymakci, N., Sosson, M., Barrier, E., Avagyan, A., 2012. Evidence for $\sim 80-75$ Ma subduction jump during Anatolide-Tauride-Armenian block accretion and $\sim 48$ Ma Arabia-Eurasia collision in Lesser Caucasus-East Anatolia Journal of Geodynamics 56-57, 76-85.

Rudnick, R.L., Gao, S., 2003. Composition of the continental crust, in: Holland, H.D.,Turekian, K.K. (Eds.), The crust, Treatise on geochemistry, pp. 1-65.

Sillitoe, R., 2010. Porphyry Copper Systems, Economic Geology 105, 3-41.

Slăma, J., Kosler, J., Condon, D.J., Crowley, J.L., Gerdes, A., Hanchar, J.M., Horstwood, M.S.A., Morris, G.A., Nasdala, L., Norberg, N., Schaltegger, U., Schoene, B., Tubrett, M.N., Whitehouse, M.J., 2008. Plešovice zircon - A new natural 
reference material for $\mathrm{U}-\mathrm{Pb}$ and $\mathrm{Hf}$ isotopic microanalysis. Chemical Geology 249, $1-$ 35.

Soylu, M., 1999. Modeling of porphyry copper mineralization of the Eastern Pontides. Ph.D. thesis, Middle East Technical University, 127 p.

Stephenson, R., Schellart, W.P., 2010. The Black Sea back-arc basin: insights to its ori- gin from geodynamic models of modern analogues, in: Sosson, M., Kaymakci, N., Stephanson, R., Bergarat, F., Storatchenoko, V. (Eds.), Sedimentary Basin Tectonics from the Black Sea and Caucasus to the Arabian Platform. Geological Society of London Special Publication 340, pp. 11-21.

Sun, S.S., McDonough, W.F., 1989. Chemical and isotopic systematics of ocean basalts: Implications for mantle composition and processes, in: Saunder, A.D., Nory, M.J. (Eds.), Magmatism in Ocean Basins. London, Geology Society Special Publications 42, pp. 313-345.

Şen, C., 2007. Jurassic volcanism in the Eastern Pontides: is it rift related or subduction related? Turkish Journal of Earth Sciences 16, 523-539.

Şengör, A.M.C., Yılmaz, Y., 1981. Tethyan evolution of Turkey; A plate tectonic approach. Tectonophysics 75, 181-241.

Şengör, A.M.C., Yılmaz, Y., Ketin, I., 1980. Remnants of a pre-Late Jurassic ocean in northern Turkey: Fragments of Permian-Triassic Paleo-Tethys. Geological Society of America Bulletin Part I 91, 599-609. 
Taner, M.F., 1977. Etudé géologique et pétrographique de la région de Güneyceİkizdere, située au sud de Rize (Pontides orientales, Turquie). Ph.D thesis, (in French), Université de Geneve.

Taylor, R.P., Fryer, B.J., 1980. Multiple-stage hydrothermal alteration in porphyry copper system in northern Turkey: The temporal interplay of potassic, propylitic and phyllic fluids. Canadian Journal of Earth Sciences 17. 901-927.

Topuz, G., Altherr, R., Schwarz, W.H., Dokuz, A., Meyer, H.P., 2007. Variscan amphibolite facies metamorphic rocks from the Kurtoğlu metamorphic complex (Gümüşhane area, eastern Pontides, Turkey). International Journal of Earth Sciences 96, 861-873.

Topuz, G., Altherr, R., Siebel, W., Schwarz, W.H., Zack, T., Hasözbek, A., Barth, M., Satır, M., Şen, C., 2010. Carboniferous high-potassium I-type granitoid magmatism in the eastern Pontides: the Gümüşhane pluton (NE Turkey). Lithos 116, 92-110.

Topuz, G., Okay, A. I., Altherr, R., Schwarz, W. H., Siebel, W., Zack, T., Satır, M., Şen, C., 2011. Post-collisional adakite-like magmatism in the Ağvanis Massif and implications for the evolution of the Eocene magmatism in the Eastern Pontides (NE Turkey). Lithos 125(1-2), 131-150.

Topuz, G., Çelik, Ö.F., Şengör, A. M.C., Altıntaş, I.E., Zack, T., Rolland, Y., Barth, M., 2013a. Jurassic ophiolite formation and emplacement as backstop to a subductionaccretion complex in northeast Turkey, the refahiye ophiolite, and relation to the Balkan ophiolites. American Journal of Science 313, 1054-1087. 
Topuz, G., Göçmengil, G., Rolland, Y., Çelik, Ö. F., Zack, T. \& Schmitt, A. K. $2013 b$. Jurassic accretionary complex and ophiolite from northeast turkey: no evidence for the Cimmerian continental ribbon. Geology 41, 255-258.

Topuz, G., Okay, A.., Altherr, R., Schwarz, W.H., Sunal, G., Altınkaynak, L., 2014. Triassic warm subduction in northeast Turkey: Evidence from the Ağvanis metamorphic rocks. Island Arc 23, 181-205.

Ulianov, A., Muntener, O., Schaltegger, U., Bussy, F., 2012. The data treatment dependent variability of U-Pb zircon ages obtained using mono-collector, sector field, laser ablation ICPMS. Journal of Analytical Atomic Spectrometry 27, 663-676.

Ustaomer, T., Robertson, H.F.A., 2010. Late Paleozoic-Early Cenozoic tectonic development of the Eastern Pontides (Artvin area), Turkey: stages of closure of Tethys along the southern margin of Eurasia. Special Publications, Geological Society London 340, 281-327.

Ustaömer, T., Robertson, H.F.A., Ustaömer, P.A., Gerdes, A., Peytcheva, I., 2012. Constraints on Variscan and Cimmerian magmatism and metamorphism in the Pontides (Yusufeli-Artvin area), NE Turkey from U-Pb dating and granite geochemistry, in: Robertson, A.H.F., Parlak, O., Ünlügenç, U.C. (Eds), Geological Development of Anatolia and the Easternmost Mediterranean Region. Geological Society, London, Special Publications, 372, pp. 49-75.

Vigneresse, J.L., 2007. The role of discontinuous magma inputs in felsic magma and ore generation. Ore Geology Reviews 30, 181-216. 
Wallace, P., Carmichael, I.S.E., 1992. Alkaline and calcalkaline lavas near Los Volcanes, Jalisco, Mexico - geochemical diversity and its significance in volcanic arcs. Contributions to Mineralogy and Petrology 111, 423-439.

Whalen, J. B., Jenner, G. A., Longstaffe, F. J., Robert, F., Gariepy, C., 1996. Geochemical and isotopic $(\mathrm{O}, \mathrm{Nd}, \mathrm{Pb}$ and $\mathrm{Sr})$ constraints on A-type granite petrogenesis based on the Topsails igneous suite, Newfoundland Appalachians. Journal of Petrology 37, 1463- 1489.

Winchester, J.A., Floyd, P.A., 1977. Geochemical discrimination of different magma series and their differentiation products using immobile elements. Chemical Geology 20, 325-343.

Yalçınalp, B., 1992. Güzelyayla (Maçka-Trabzon) Porfiri Cu-Mo cevherleşmesinin jeolojik yerleşimi ve jeokimyası. Ph.D thesis, (in Turkish), Trabzon, Karadeniz Technical University, 175p.

Yalçınalp, B., 1995. Doğu Pontidler'de Porfiri Cu-Mo Mineralleşmeleri içeren Granitoyilerin Jeokimyasal Özellikleri, Geological Bulletin of Turkey 38(1), 25-32.

Yavuz, F., 1992. Doğu Karadeniz metalojenik provensinde Balcılı (Artvin) ve Güzelyayla (Trabzon) Bakır-Molibden oluşumlarının jenetik etüdü. Ph.D thesis, (in Turkish), İstanbul, İstanbul Technical University, 190p.

Yiğit, O., 2009. Mineral deposits of Turkey in relation to Tethyan metallogeny: Implications for future mineral exploration. Economic Geology 104, p. 19-51. 
Yılmaz, Y., Tuysuz, O., Yiğitbaş, E. Genc, C., Şengor, A.M.C., 1997. Geology and tectonic evolution of the Pontides, in: Robinson, A.G. (Ed.), Regional and Petroleum Geology of the Black Sea and Surrounding Region. AAPG Memoir 68, pp. 183-226.

Zartman, R.E., Doe, B.R., 1981. Plumbotectonics-the model. Tectonophysics 75, 135-162. doi:http://dx.doi.org/10.1016/0040-1951(81)90213-4.

Zhao, J-H., Zhou, M-F., 2007. Geochemistry of Neoproterozoic mafic intrusions in the Panzhihua district (Sichuan Province, SW China): Implications for subduction-related metasomatism in the upper mantle. Precambrian Research 152, $27-47$.

Zindler, A., Hart, S., 1986. Chemical Geodynamics. Annual Review of Earth and Planetary Sciences 14, 493-571. doi:10.1146/annurev.ea.14.050186.002425.

\section{Figure Captions}

Figure 1: Simplified regional geological map of the Eastern Pontides and location of the Elbeyli $\mathrm{Mo} \pm \mathrm{Cu}$, Emeksen Mo, Güzelyayla $\mathrm{Cu}-\mathrm{Mo}$ and Ulutaş Cu-Mo prospects (modified after MTA, 2002). The inset shows the major tectonic units of Anatolia (simplified after Okay and Tüysüz, 1999).

Figure 2: Time ( $\mathrm{Ma})$ vs. tectonic regime/magmatism diagram summarizing the geodynamic evolution of the Eastern Pontides during Paleo-Tethyan and NeoTethyan evolution and the setting of the different types of ore deposits (Porphyry-, VMS- and epithermal-type). (Compilation of existing geochronological and geochemical data of the Eastern Pontides from: Altherr et al., 2008; Arslan and 
Aslan, 2006; Dokuz et al., 2010; Eyüboğlu et al., 2014; Karslı et al., 2010; 2011; 2012a; Kaygusuz and Şen, 2011; Kaygusuz et al., 2009; Okay, 2008; Okay and Şahintürk, 1997; Okay and Tüysüz, 1999; Şengör et al., 1980; Topuz et al., 2010; 2011). Alternate geodynamic models for the Eastern Pontides are shown in red color (Eyüboğlu, 2010; Hässig et al., 2013).

Figure 3: Geochemical classification and discrimination diagrams. a -Geochemical classification of host rocks based on $\mathrm{Nb} / \mathrm{Y}$ vs. $\mathrm{Zr} / \mathrm{TiO}_{2}$ (Winchester and Floyd, 1977). b - $\mathrm{SiO}_{2}$ (wt.\%) vs. $\mathrm{Na}_{2} \mathrm{O}+\mathrm{K}_{2} \mathrm{O}$ (wt.\%) alkaline, sub-alkaline classification diagram. c AFM plot of Irvine and Baragar (1971), A: $\mathrm{Na}_{2} \mathrm{O}+\mathrm{K}_{2} \mathrm{O}$ (wt.\%); F: FeOt (wt.\%) ; M: $\mathrm{MgO}$ (wt.\%). d - $\mathrm{SiO}_{2}$ (wt.\%) vs. $\mathrm{K}_{2} \mathrm{O}$ (wt.\%) for the magmatic host rocks at Elbeyli, Emeksen, Guzelyayla and Ispir-Ulutaş (tholeiitic, calc-alkaline, high-K calc-alkaline and shoshonitic compositional fields from Peccerillo and Taylor, 1975). Geochemical data for Güzelyayla and Ulutaş are from Yalçınalp (1992) and Taylor and Frey (1980), respectively.

Figure 4: $\mathrm{SiO}_{2}$ (wt. \%) vs. major oxides (wt. \%) and representative trace elements (ppm) for samples from the Elbeyli and Emeksen prospects.

Figure 5: a - $\mathrm{Sr} / \mathrm{Y}$ vs. $\mathrm{Y}(\mathrm{ppm})$. b - $\mathrm{Sr} / \mathrm{Y}$ vs. $\mathrm{SiO}_{2}$ (wt. \%). c - La/Yb vs. $\mathrm{SiO}_{2}$ (wt. \%) for samples from Elbeyli, Emeksen and Güzelyayla. The adakite and "volcanic" arc fields are from Castillo et al. (1999), Defant and Drummond (1990) and Richards et al. (2012). Geochemical data for Güzelyayla taken from Yalçınalp (1992). 
Figure 6: Primitive mantle-normalized (Sun and McDonough, 1989) multi-element diagrams. Upper crust and lower crust data from Rudnick and Gao (2003). a - Elbeyli monzonite samples. b - Emeksen porphyritic granite, granite and granodiorite samples. c - Emeksen diorite samples. d - Güzelyayla dacite porphyry and IspirUlutaş granite porphyry samples. Geochemical data for Güzelyayla and Ulutaş intrusions were taken from Yalçınalp (1992) and Taylor and Frey (1980), respectively.

Figure 7: Chondrite-normalized REE diagrams (Boynton 1984). Upper crust and lower crust data from Rudnick and Gao (2003). a - Elbeyli monzonite samples. b Emeksen porphyritic granite, granite and granodiorite samples. c - Emeksen diorite samples.

Figure 8: ${ }^{206} \mathrm{~Pb} / 238 \mathrm{U}$ weighted mean ages, concordia plots and cumulative probability density function curves. All reported errors are $2 \sigma$. a - Elbeyli monzonite sample (OFA-1). b - Emeksen porphyry granite sample (GE-1). c - Emeksen granodiorite sample (GE-2). d - Emeksen granite sample (GE-4).

Figure 9: ${ }^{206} \mathrm{~Pb} /{ }^{238} \mathrm{U}$ weighted mean ages, concordia plots and cumulative probability density function curves. All reported errors are $2 \sigma$. a - Güzelyayla dacite porphyry sample (TMG-1), inset shows xenocrystic cores of zircons. b - Ispir-Ulutaş quartz porphyry sample (Ei-1). c - Ispir-Ulutaş granite porphyry sample (Ei-3).

Figure 10: a $-{ }^{143} \mathrm{Nd} /{ }^{144} \mathrm{Nd}$ (i) vs. ${ }^{87} \mathrm{Sr}^{86} \mathrm{Sr}_{(i)}$ plot of samples from the Elbeyli and Emeksen prospects. The composition of present-day CHUR was calculated for a 
Late Cretaceous age at $80 \mathrm{Ma}$. DMM: Depleted MORB and BSE: Bulk silicate earth (BSE) are from Zindler and Hart, (1986). b - ${ }^{87} \mathrm{Sr}^{26} \mathrm{Sr}_{(i)}$ vs. $\mathrm{SiO}_{2}$ (wt.\%) for Elbeyli and Emeksen samples. c- ${ }^{143} \mathrm{Nd} /{ }^{144} \mathrm{Nd}$ (i) vs. $\mathrm{SiO}_{2}$ (wt.\%) for Elbeyli and Emeksen samples. d- ${ }^{207} \mathrm{~Pb} /{ }^{204} \mathrm{~Pb}$ (i) vs. ${ }^{206} \mathrm{~Pb} / 204 \mathrm{~Pb}_{\text {(i) }}$ plot of samples from the Elbeyli and Emeksen prospects. Upper crust and orogen evolution curves are from Zartman and Doe, (1981). DMM: Depleted MORB is from Zindler and Hart, (1986). The Sr, Nd and $\mathrm{Pb}$ isotopic compositions of the Gümüşhane pluton (Topuz et al., 2011), the Köprübaşı pluton (Kaygusuz and Şen, 2011), the Harşit pluton (Karslı et al., 2010), the Pirnalli pluton (Karslı et al., 2012a), the Camiboğazı pluton (Kaygusuz et al., 2014), the Seme quartz diorite (Topuz et al., 2011), and the Sisdağ pluton (Karslı et al., 2012b) are plotted for comparison.

Figure 11: $\mathrm{Dy} / \mathrm{Yb}(\mathbf{a})$, and $\mathrm{Zr} / \mathrm{Sm}$ (b) vs. $\mathrm{SiO}_{2}$ (wt.\%). c - $\varepsilon N d(T)$ vs. $\mathrm{Gd} / \mathrm{Yb}$. (c), d Th/Yb vs. Ta/Yb diagram after Pearce (1983) and trends from Abratis (1998) (d).

Figure 12: a - Ba/Nb vs. $\mathrm{Nb}(\mathrm{ppm})$, partial melting, fractional crystallization and slab input trends from Kamvong et al., (2014). b - Rb/Y vs. Nb/Y, fluid-related and meltrelated enrichment trends were taken from Zhao and Zhou, (2007). c - La/Sm vs. $\mathrm{Sm} / \mathrm{Yb}$, pressure-dependent changes from pyroxene to garnet were taken from Kay and Kay, (1991). d - La/Sm vs. $\mathrm{SiO}_{2}$ (wt.\%).

Figure 13: $\mathrm{Zr} / \mathrm{Sm}$ vs. $\mathrm{Nb} / \mathrm{Ta}$. Lines represent primitive mantle values from Sun and McDonough (1989). Rutile eclogite and amphibolite/hornblende eclogite melting fields from Kamvong et al. (2014). 
Figure 14: $\mathrm{V} / \mathrm{Sc}$ vs. $\mathrm{MgO}$ (wt.\%) for samples from the Elbeyli and Emeksen prospects Diagram based on Lee et al. (2005) and Kamvong et al. (2014). Data of Eocene adakitic samples from Karslı et al. (2011) are plotted for comparison. 


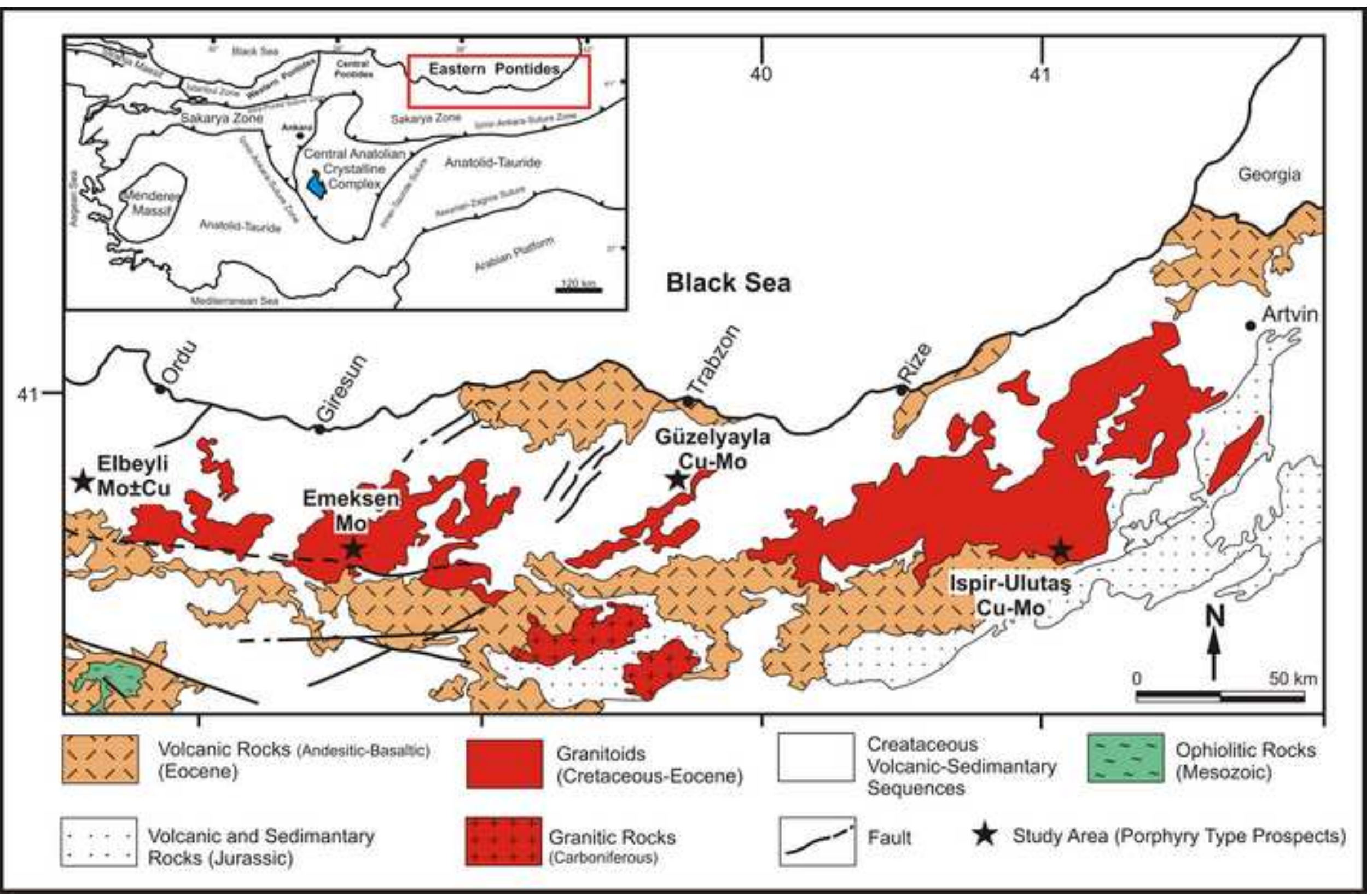




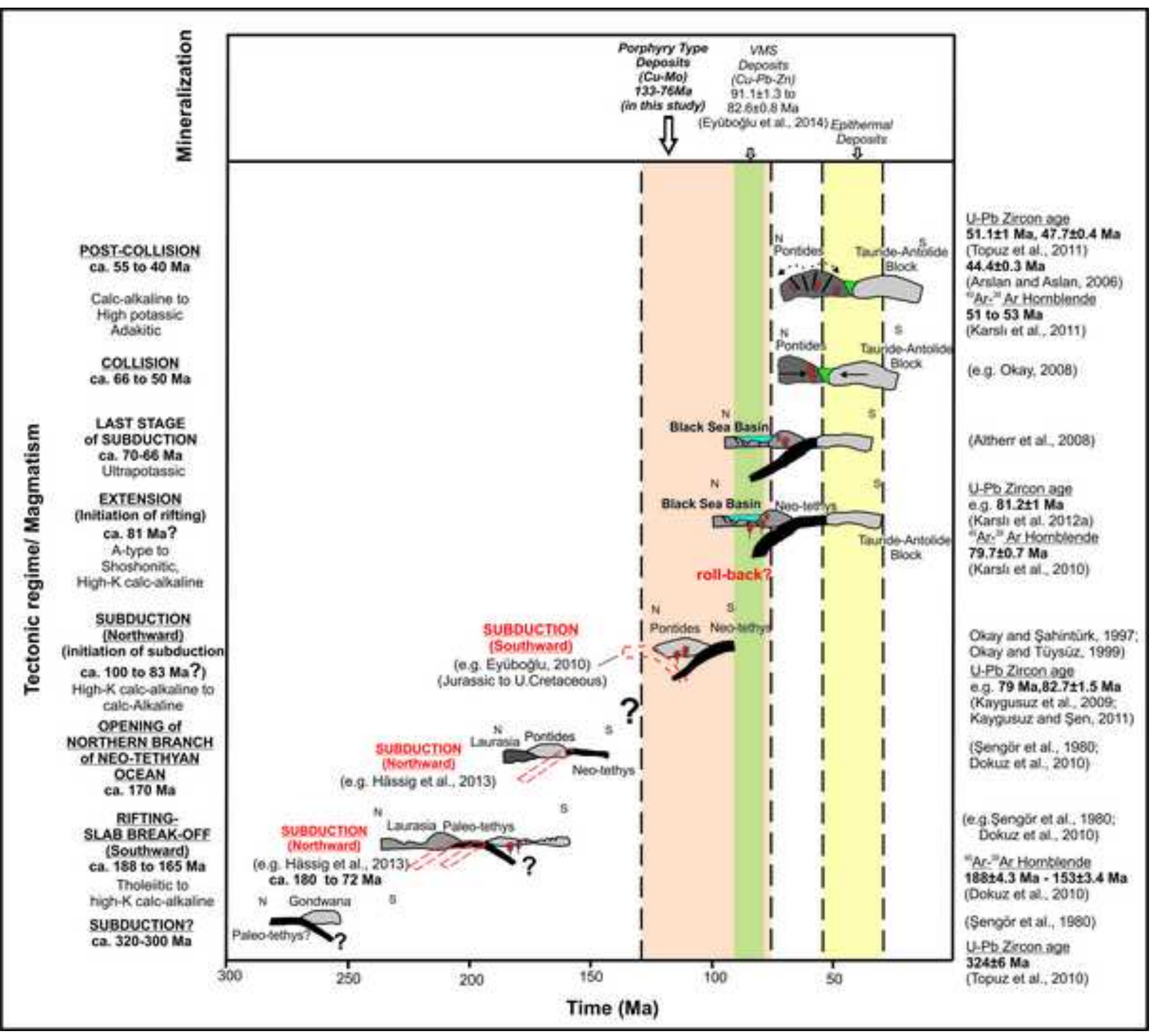



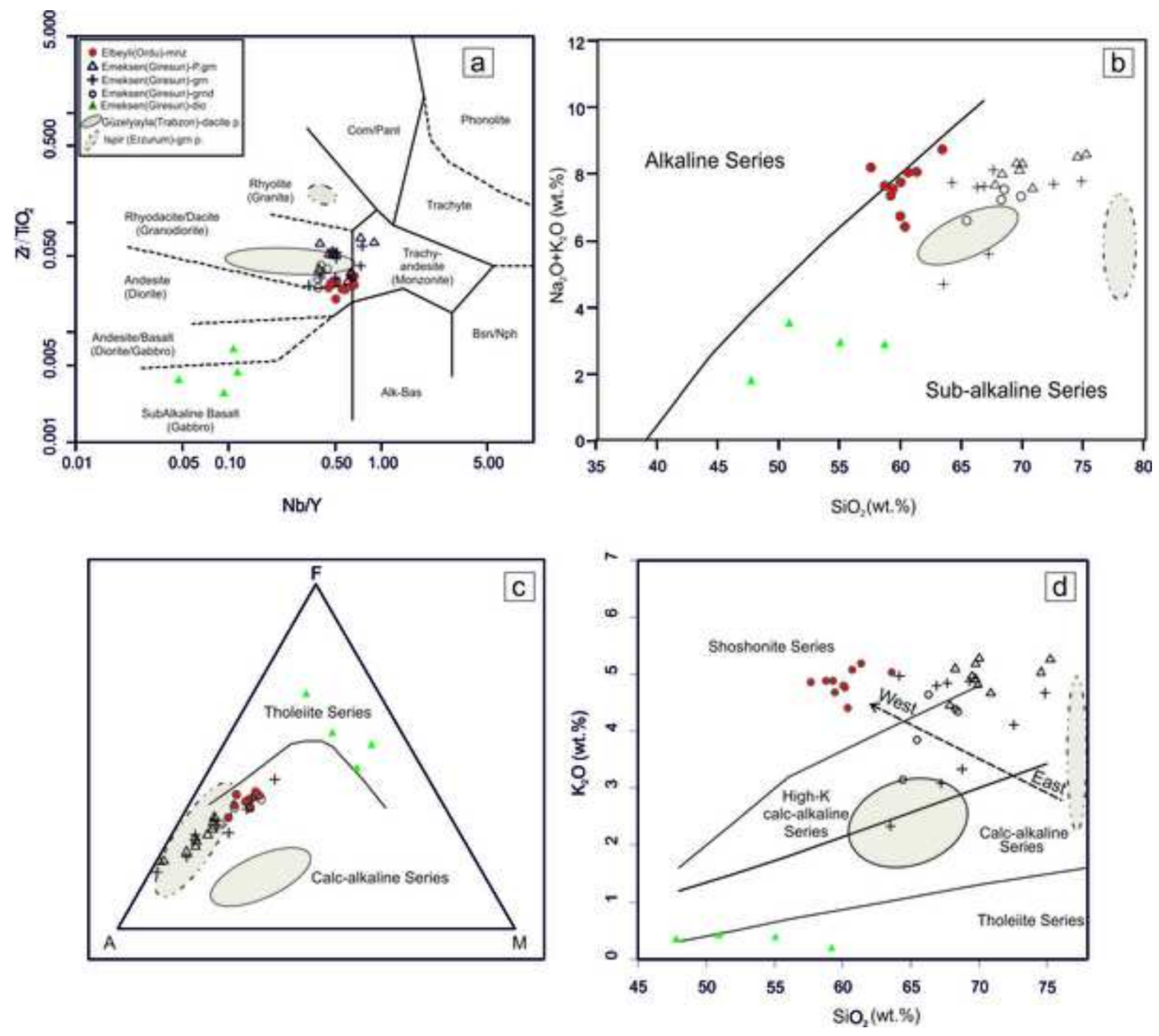


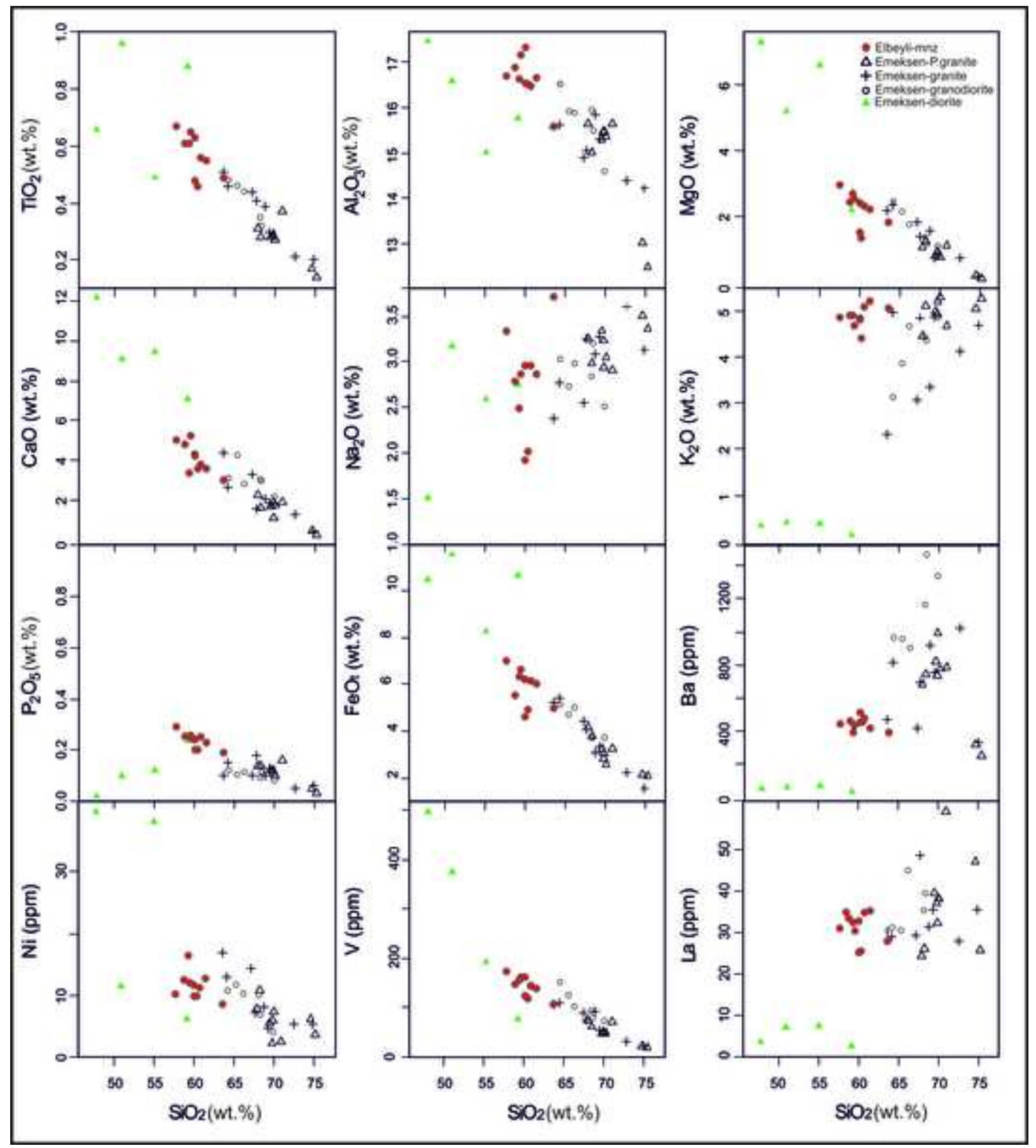



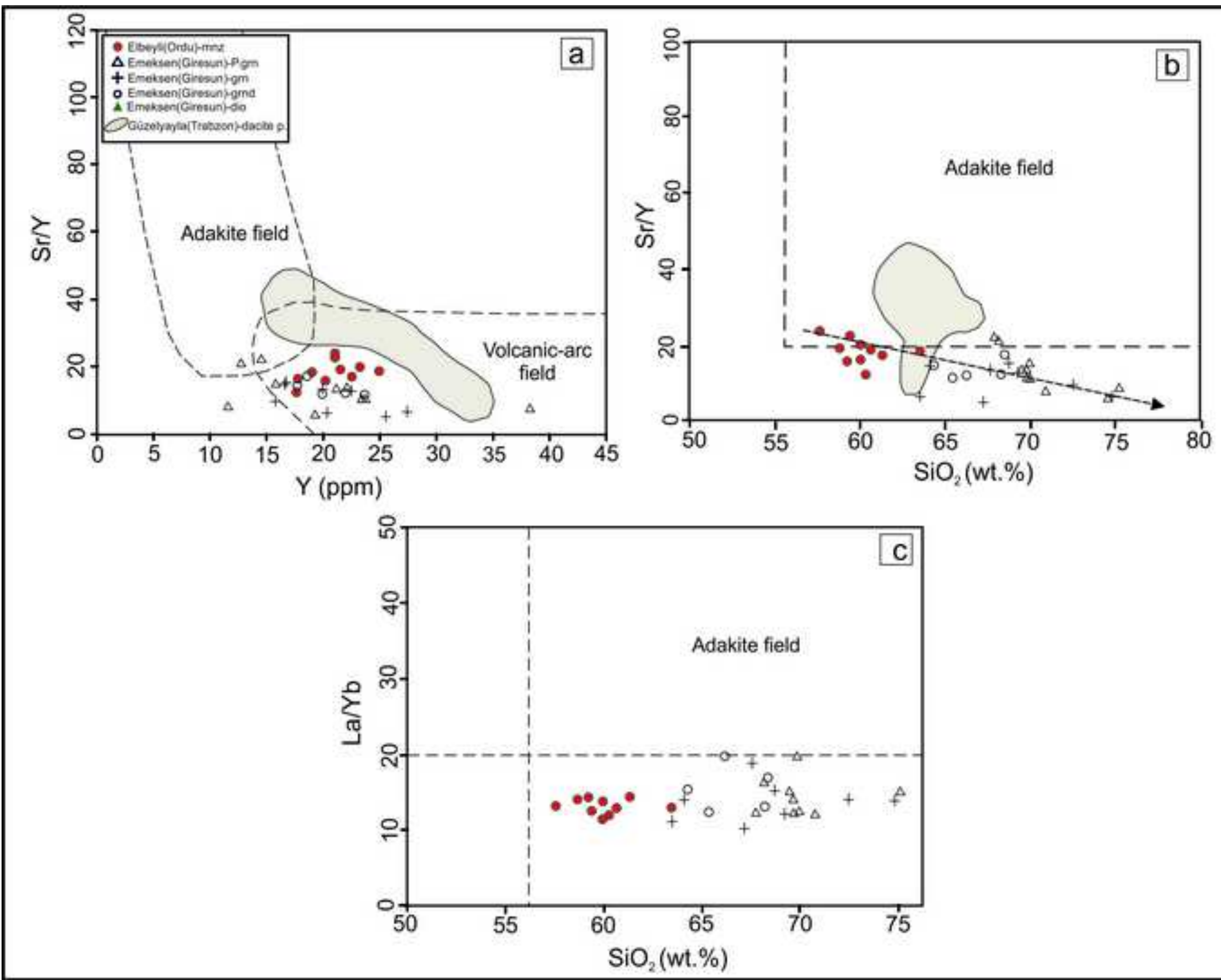



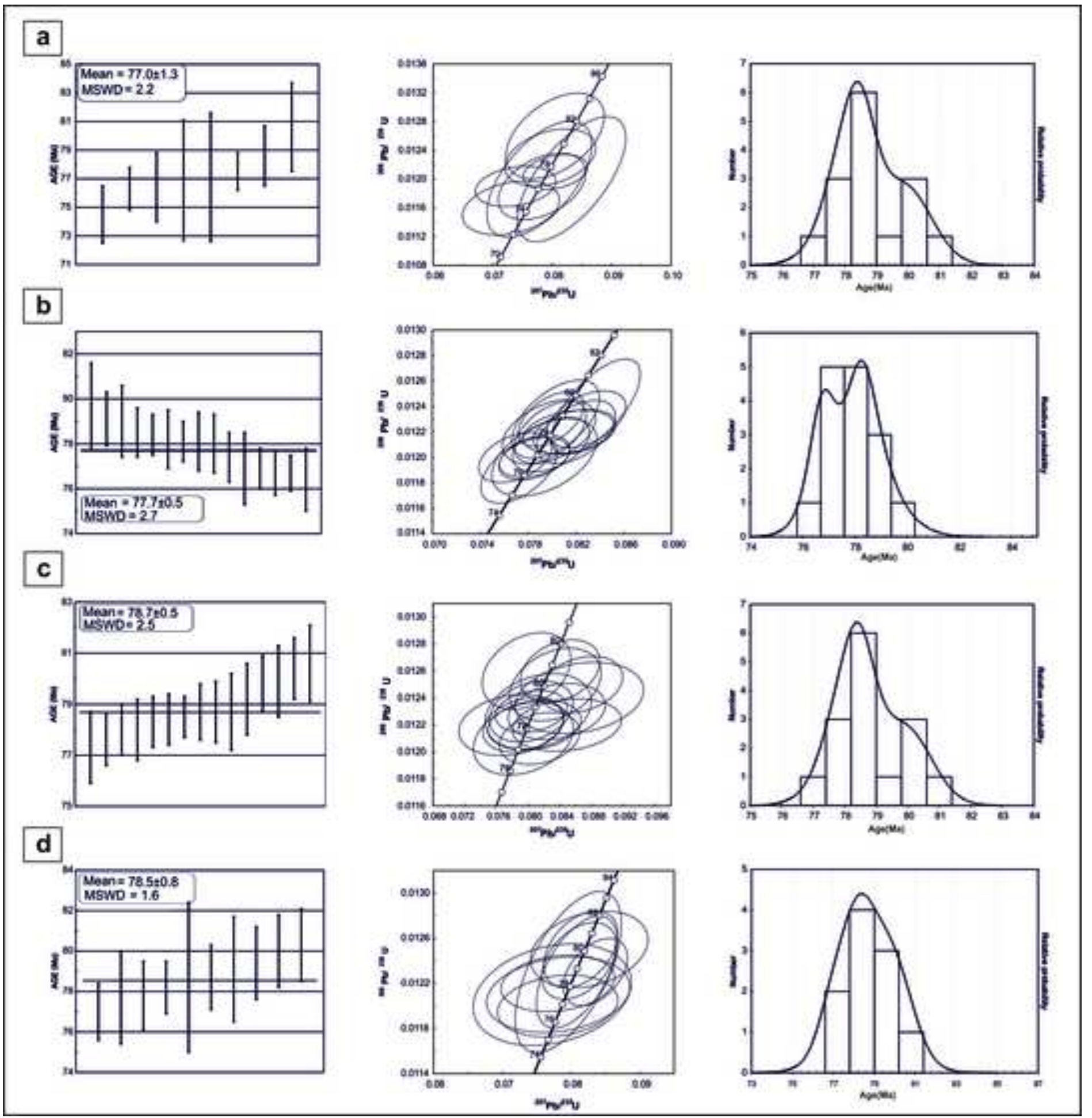




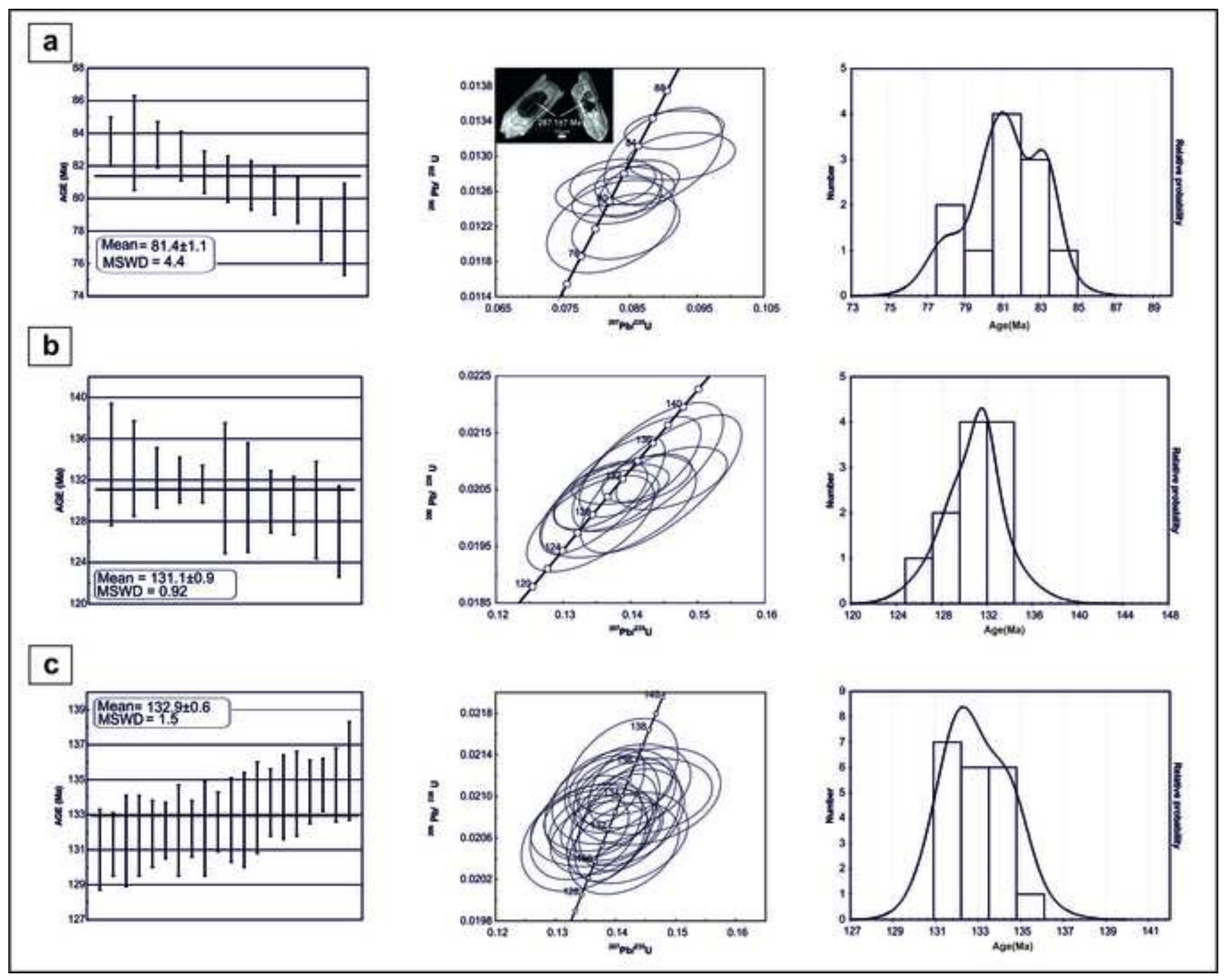



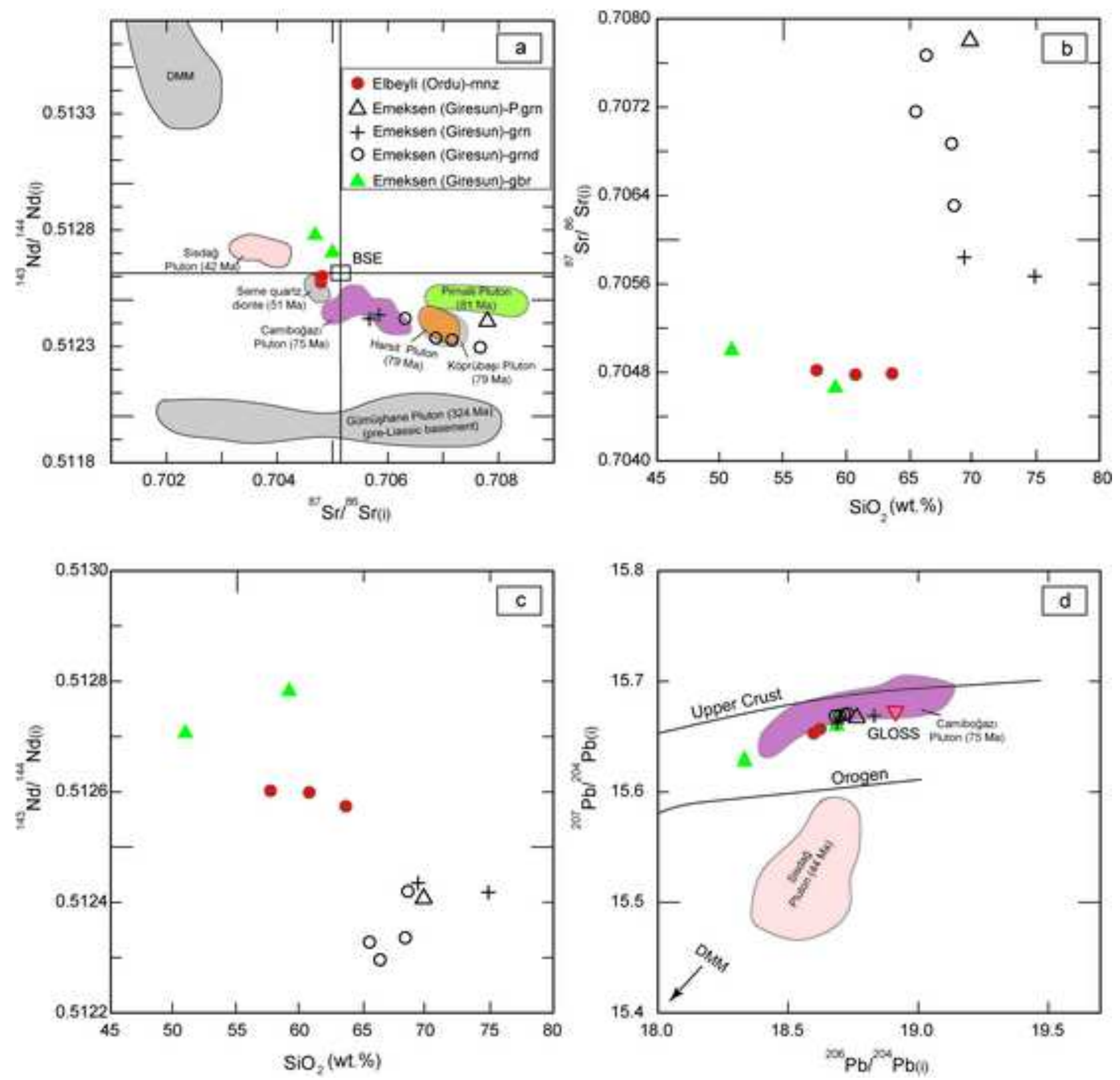

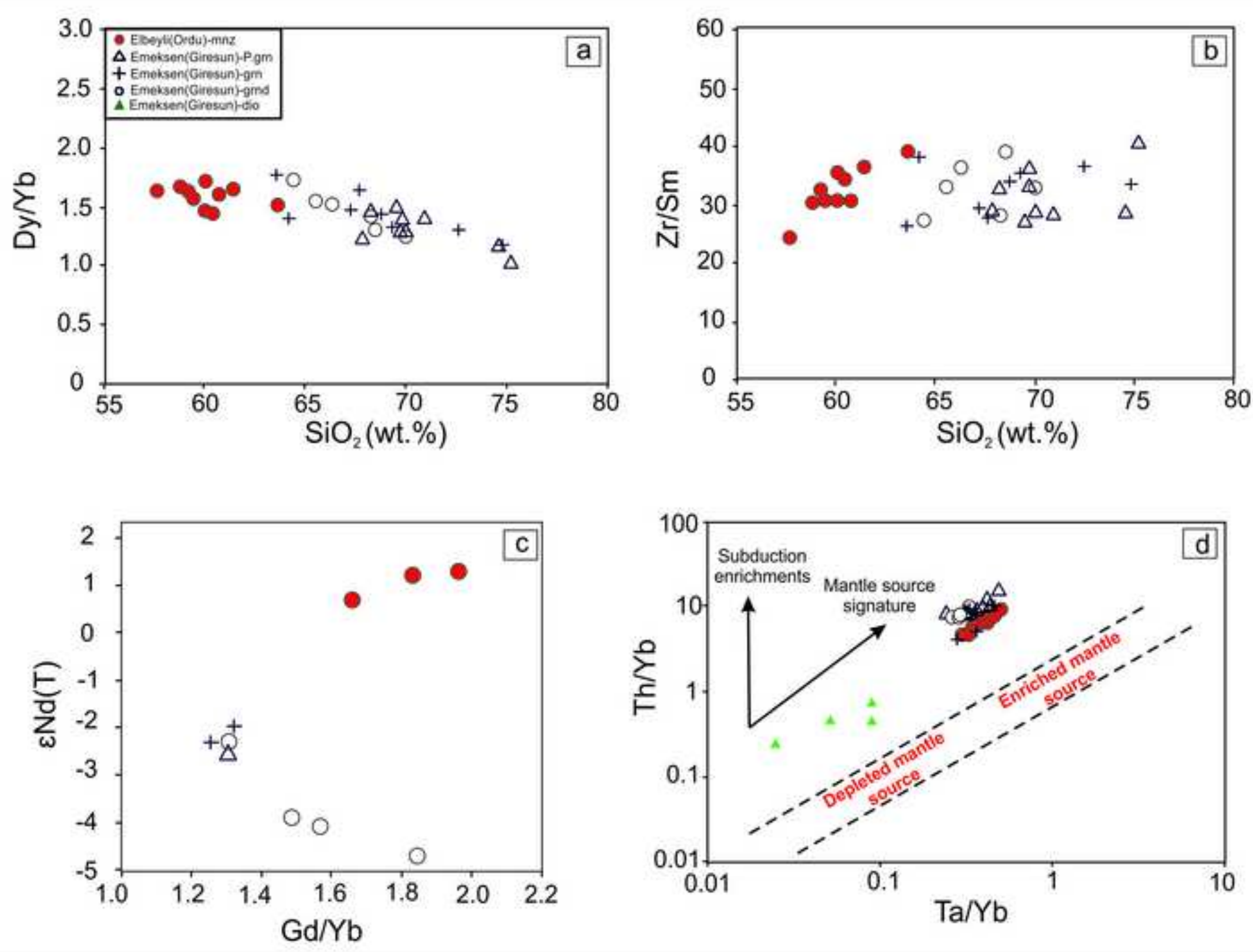

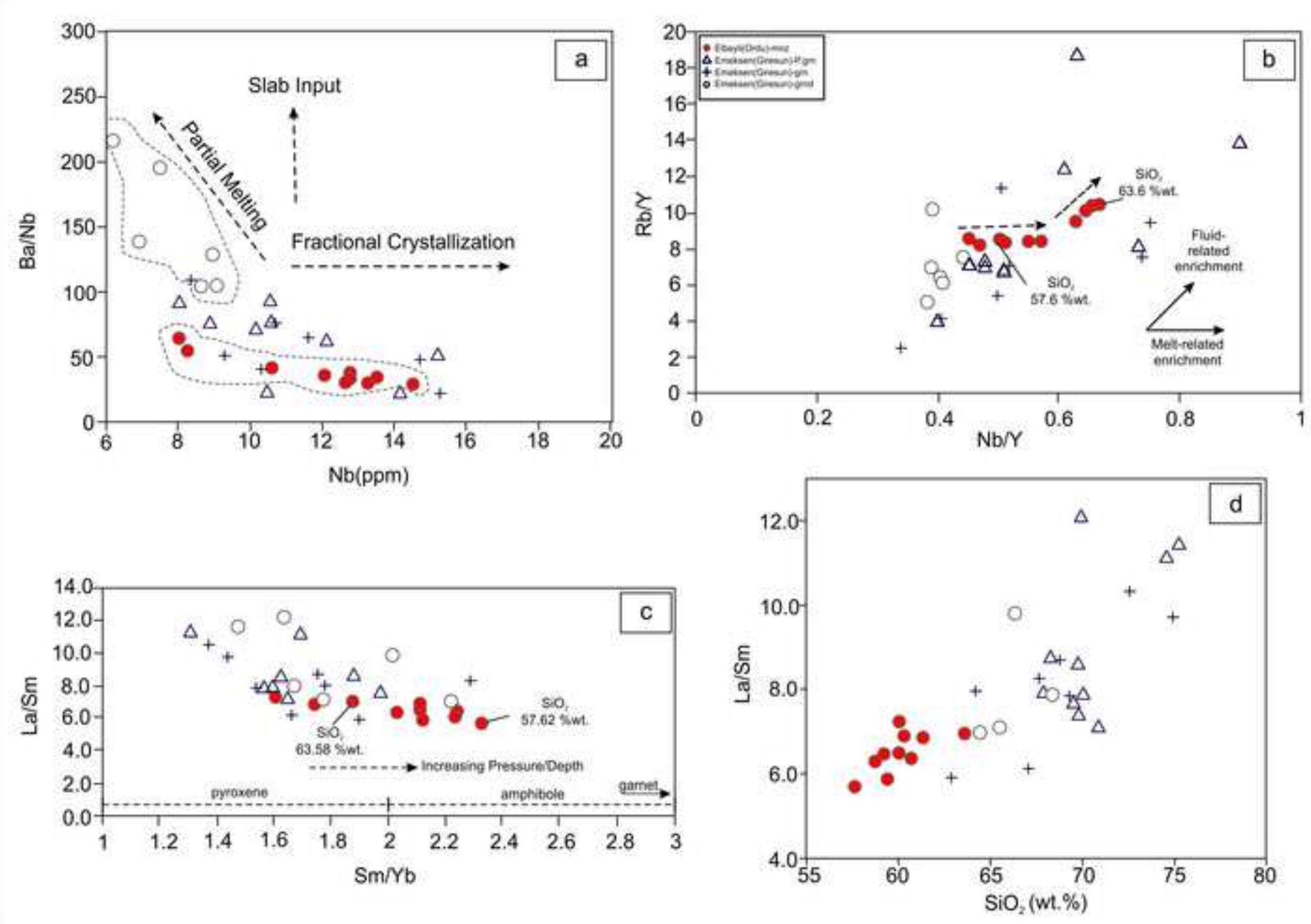


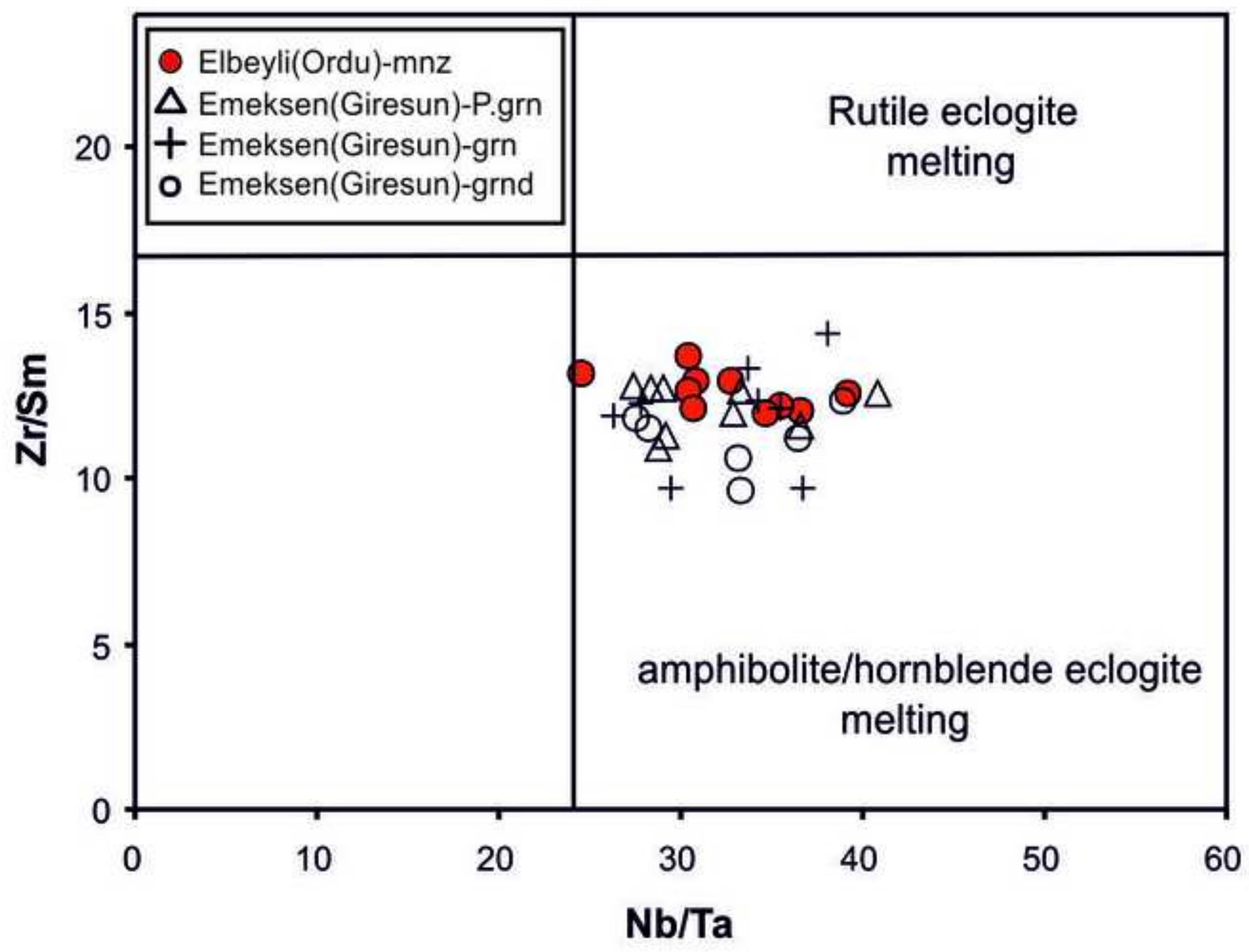




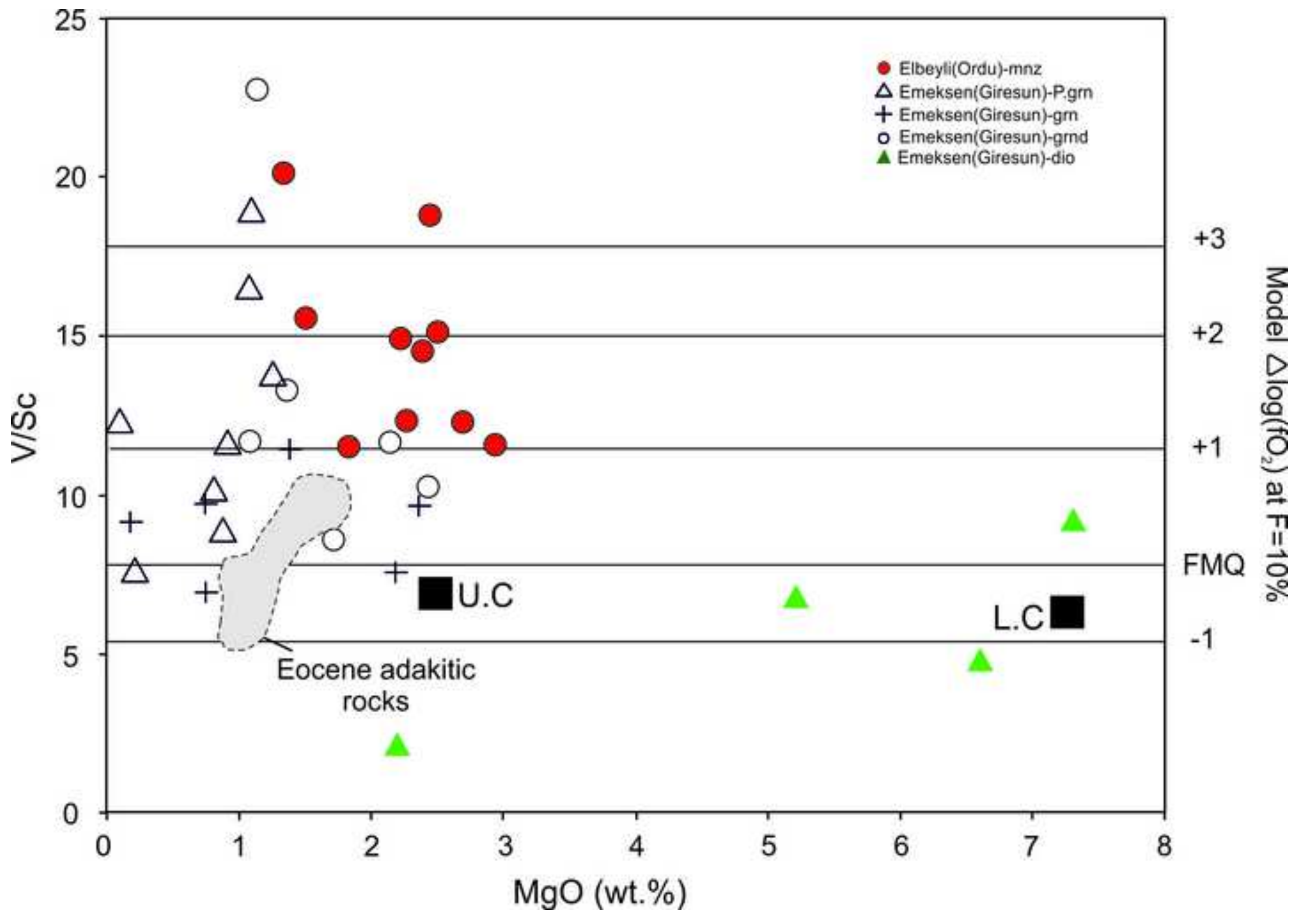


Table1. Classification of the Elbeyli, Emeksen, Güzelyayla and Ispir-Ulutaş prospects based on their age and geochemical characteristics of the host rocks, ore types and ore geometries.

\begin{tabular}{|c|c|c|c|c|}
\hline Prospect Name & $\begin{array}{l}\text { Elbeyli } \\
\text { (Ordu) }\end{array}$ & $\begin{array}{l}\text { Emeksen } \\
\text { (Giresun) }\end{array}$ & $\begin{array}{l}\text { Güzelyayla } \\
\text { (Trabzon) }\end{array}$ & $\begin{array}{l}\text { Ispir-Ulutaş } \\
\text { (Erzurum) }\end{array}$ \\
\hline Principal host rocks & $\begin{array}{c}\text { Monzonite } \\
\text { Monzodiorite }\end{array}$ & $\begin{array}{l}\text { Granodiorite } \\
\text { Granite } \\
\text { Porphyritic } \\
\text { granite }\end{array}$ & Dacite Porphyry & $\begin{array}{l}\text { Granite Porphyry } \\
\text { Quartz Porphyry }\end{array}$ \\
\hline $\begin{array}{c}\text { Geochemical } \\
\text { classifications of } \\
\text { host-rock }\end{array}$ & Shoshonitic, I- type & $\begin{array}{l}\text { Shoshonitic to } \\
\text { High-K Calc- } \\
\text { alkaline, I- type }\end{array}$ & $\begin{array}{l}\text { Calc-alkaline to } \\
\text { Adakitic, I- type }\end{array}$ & $\begin{array}{l}\text { Calc-alkaline, I- } \\
\text { type }\end{array}$ \\
\hline $\begin{array}{l}\text { Age of host rocks } \\
\text { (mean) }\end{array}$ & $\begin{array}{c}\text { LA-ICP-MS- Zircon U-Pb } \\
77 \pm 1 \mathrm{Ma} \\
\text { (Monzonite/Monzodiorite) } \\
\text { (in this study) }\end{array}$ & $\begin{array}{c}\text { LA-ICP-MS- } \\
\text { Zircon U-Pb } \\
78 \pm 0.5 \mathrm{Ma} \\
\text { (P.granite) } \\
78.5 \pm 1 \mathrm{Ma} \\
\text { (Granite) } \\
79 \pm 0.5 \mathrm{Ma} \\
\text { (Granodiorite) } \\
\text { (in this study) }\end{array}$ & $\begin{array}{c}\text { LA-ICP-MS- } \\
\text { Zircon U-Pb } \\
81.5 \pm 1 \mathrm{Ma} \text { (Dacite } \\
\text { P.) } \\
\text { (in this study) }\end{array}$ & $\begin{array}{l}\text { LA_ICP-MS- } \\
\text { Zircon U-Pb } \\
133 \pm 0.5 \mathrm{Ma} \\
\text { (Granite P.) } \\
131.1 \pm 1 \mathrm{Ma} \\
\text { (Quartz P.) } \\
\text { (in this study) }\end{array}$ \\
\hline Alteration types & $\begin{array}{c}\text { Advanced Argillic } \\
\text { Phyllic }\end{array}$ & $\begin{array}{c}\text { Potassic } \\
\text { Phyllic } \\
\text { Pyropylitic }\end{array}$ & $\begin{array}{c}\text { Potassic } \\
\text { Phyllic } \\
\text { Pyropylitic }\end{array}$ & $\begin{array}{c}\text { Phyllic } \\
\text { Pyropylitic }\end{array}$ \\
\hline Orebody & $\begin{array}{l}\text { Fracture-controlled NW- } \\
\text { oriented quartz veins }\end{array}$ & $\begin{array}{l}\text { NW-, and NS- } \\
\text { striking } \\
\text { vertical/sub- } \\
\text { vertical quartz } \\
\quad \text { veins }\end{array}$ & $\begin{array}{c}\text { Stockwork } \\
\text { Dissemination }\end{array}$ & $\begin{array}{c}\text { Stockwork } \\
\text { NW-striking } \\
\text { vertical/sub- } \\
\text { vertical quartz } \\
\text { veins } \\
\text { Dissemination }\end{array}$ \\
\hline Ore minerals & $\begin{array}{c}\text { Pyrite, } \\
\text { Molybdenite, } \\
\text { Chalcopyrite, } \\
\text { Fahlore, } \\
\text { Enargite }\end{array}$ & $\begin{array}{l}\text { Molybdenite } \\
\text { Pyrite } \\
\pm \text { Fahlore } \\
\pm \text { Sphalerite } \\
\pm \text { Galena }\end{array}$ & $\begin{array}{c}\text { Chalcopyrite } \\
\text { Molybdenite } \\
\text { Pyrite } \\
\text { Pyrrhotite } \\
\pm \text { Covellite } \\
\pm \text { Chalcocite } \\
\pm \text { Digenite }\end{array}$ & $\begin{array}{c}\text { Chalcopyrite } \\
\text { Pyrite } \\
\text { Pyrrhotite } \\
\text { Sphalerite } \\
\text { Molybdenite } \\
\pm \text { Galena } \\
\pm \text { Covellite }\end{array}$ \\
\hline $\begin{array}{c}\text { Reserves/Resource } \\
\text { and Grade }\end{array}$ & $\begin{array}{l}\text { No Reserve and Grade } \\
\text { Data }\end{array}$ & $\begin{array}{c}\text { No Reserve Data } \\
\text { Available } \\
0.08 \% \text { to } 2.87 \%\end{array}$ & $\begin{array}{l}186.2 \mathrm{Mt} \text { at } \\
0.3 \% \mathrm{Cu} \text { and }\end{array}$ & $\begin{array}{c}73.6 \mathrm{Mt} \text { at } 0.31 \% \\
\mathrm{Cu} \text { and } 0.022 \\
\% \mathrm{Mo}^{*}\end{array}$ \\
\hline
\end{tabular}




\begin{tabular}{|c|c|c|c|c|}
\hline & Available & $\mathrm{Mo}^{*}$ & $\begin{array}{c}0.002-0.021 \% \\
\mathrm{Mo}^{\star}\end{array}$ & \\
\hline References & & ${ }^{*} \mathrm{MTA}, 1984$ & $\begin{array}{c}{ }^{*} \text { Er et al., } 1992 \\
\text { Güner and Güç, } \\
1990\end{array}$ & $\begin{array}{c}{ }^{*} \text { Giles, } 1973 \\
\text { Soylu, } 1999 \\
\text { Yiğit, } 2009\end{array}$ \\
\hline
\end{tabular}

